\title{
ENVIRONMENTAL VARIABLES INFLUENCING THE SEVERITY OF PIERCE'S DISEASE IN CALIFORNIA GRAPEVINES
}

\author{
A Thesis \\ presented to \\ the Faculty of California Polytechnic State University, \\ San Luis Obispo
}

\author{
In Partial Fulfillment \\ of the Requirements for the Degree \\ Master of Agriculture in Plant Protection Science
}

by

Christopher James Boisseranc

June 2010 
(C) 2010

Christopher James Boisseranc

ALL RIGHTS RESERVED 


\section{COMMITTEE MEMBERSHIP}

TITLE:

Environmental Variables Influencing the Severity of Pierce's Disease in California Grapevines

AUTHOR: $\quad$ Christopher James Boisseranc

DATE SUBMITTED: June 2010

COMMITTEE CHAIR: Michael Costello Ph.D.

COMMITTEE MEMBER: Scott Steinmaus Ph.D.

COMMITTEE MEMBER: W. Keith Patterson Ph.D. 


\title{
ABSTRACT \\ ENVIRONMENTAL VARIABLES INFLUENCING THE SEVERITY OF PIERCE'S DISEASE IN CALIFORNIA GRAPEVINES
}

\author{
Christopher James Boisseranc
}

This project was designed to correlate environmental variables with the development of Pierce's Disease (PD), an infection caused by the gram negative bacterium Xylella fastidiosa (Xf), in grapes (Hopkins et al. 2002). PD is one of the most difficult crop pathogens to manage because it is vectored by insects and its continued presence in the vine is usually fatal. PD is influenced by the interaction of host, disease and vector, and probably many other environmental variables. The general objective was to study and identify the most important variables involved in the expression of Pierce's Disease.

Over a two year period, from a total of eight sites in northern and southern California data was collected on forty-five environmental variables including those relating to soil moisture, soil chemistry, soil nutritional status, vine nutritional status, vine water status, in-season and dormant season climate, incidence of $X f$ in adjacent vineyard vegetation, sharpshooter species and abundance at each location, and proximity of vineyard field sites to citrus or riparian areas.

The environmental variables were analyzed with canonical correspondence analysis (CCA) to determine significance of each as they correspond with increased disease severity. The significance of environmental variables produced by CCA indicates increased soil moisture as the leading cause for increased PD incidence; several other environmental variables positively correlate with increased disease presence. Conversely, vineyard factors identified by CCA as not conducive to disease formation may play an inhibitory role in PD severity.

We undertook polymerase chain reaction (PCR) to test for the presence of PD in vegetative samples, using a 733 base pair probe specific to $X f$. These samples indicate alternative hosts in adjacent locations which act as reservoirs of Pierce's Disease as well as verifying diseased vines within the vineyard locations.

Keywords: Canonical Correspondence Analysis, Pierce's Disease, Polymerase Chain Reaction, Xylella fastidiosa. 


\section{ACKNOWLEDGEMENTS}

I thank for their essential assistance in this project Beringer, Cain, Callaway, DeBerard, Guadagni, and Hofer vineyard teams for providing the field sites for the study. I especially thank Dr. Michael Costello and Dr. Scott Steinmaus for their assistance, knowledge, and support throughout this project. Data collection efforts came from Cal Poly students Catherine Albers, Alfredo Koch, Nova Perril, Rachel Power, Kevin Robertson, and Shawn Veysey. I am grateful to the CSU Agricultural Research Initiative (ARI) for providing funding for this study. 


\section{TABLE OF CONTENTS}

Page

LIST OF TABLES Vii

LIST OF FIGURES viii

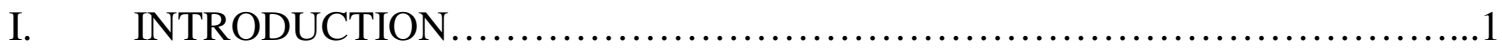

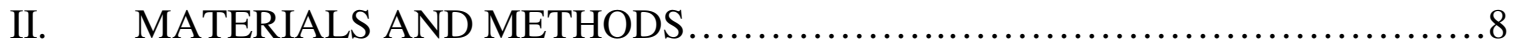

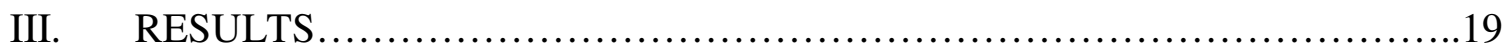

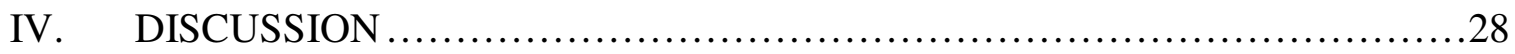

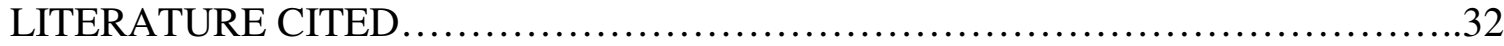

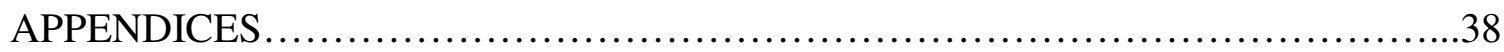




\section{LIST OF TABLES}

Table

Page

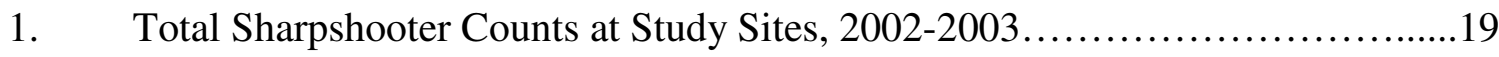

2. Visually Symptomatic Incidence of PD at Study Sites...................... 19

3. PCR Verified Incidence of $X$. fastidiosa in Study Site Vegetation ...............20

4. Soil Moisture Monitoring Data for Study Sites............................20

5. Vine Water Status Determined by PMS Pressure Bomb at Study Sites...........21

6. CIMIS Weather Data for Study Sites.................................. 21

7. Soil analysis for Study Sites............................................. 22

8. Positive Correlating Variables to Increased PD Incidence...................26

9. Negative Correlating Variables to Increased PD Incidence....................27

10. PCR Results for Alternate Vegetation Samples at Study Sites .....................38 


\section{LIST OF FIGURES}

Figure $\quad$ Page

1. Graphical Output from Canoco Correspondence Analysis.....................23

2. PD Severity and Host Plant Correspondence with Study Site $\ldots \ldots \ldots \ldots \ldots \ldots \ldots \ldots . . .23$

3. PD Severity Correspondence of Vine and Soil Nutrient Status..................24

4. PD Severity Correspondence of Climate and Habitat......................................25

5. Study Site Location Correspondence of Sharpshooter Species..................26

6. PCR Agarose Gel Image of Grapevine and Vegetation Samples.................41

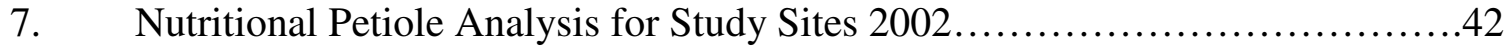

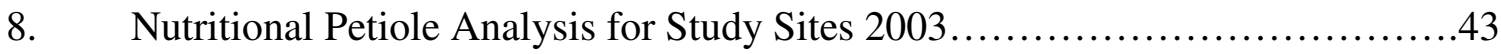




\section{INTRODUCTION}

In the cultivated grape, Vitis vinifera, infestation of Xylella fastidiosa causes an over accumulation of bacteria and bacterial secretions, plugging the xylem elements and starving the plant of nutrients and water (Hopkins 1983). Pierce's Disease is caused by blockage of the water conducting elements of the grapevine (Hopkins 1991) and once infected; grapevines typically show symptoms of drought stress. Diseased vines become non-productive and may die one or two years after infection (Goodwin et al. 1992).

Pathogen: Xylella fastidiosa. Xylella fastidiosa is a pathogenic constituent of xylem tissue causing disease in many plants including grapevine, citrus, periwinkle, almond, oleander, and coffee (Hopkins et al. 2002; Purcell et al. 1999b). Grape's Pierce's Disease strain of $X f$ also causes almond leaf scorch (Hopkins et al. 2002) and alfalfa dwarf (Frazier 1943). Some pathotypes of $X f$ have wide host ranges; strains of $X f$ cause phony peach disease, citrus blight, citrus variegated chlorosis (Phillips 1998), oleander leaf scorch, and leaf scorch in a wide range of ornamental plants (Blua et al. 1999).

DNA analyses suggest there are five distinct groups of $X f$ as of 1996 . They are the citrus group, the plum-elm group, the grape-ragweed group, the almond group, and the mulberry group (Van Sluys et al. 2003). Another strain of the bacterium was isolated in 1999 and was found to cause disease in oleander. The new strain is genetically distinct and uniform, but does not cause disease in grapes (Machado et al. 2001; Simpson et al. 2000).

$X f$ completes its lifecycle in the non-living xylem tissue of the plant, and can coexist within dozens, if not hundreds, of plant species, many of which exhibit no disease 
symptoms (Freitag 1951). In most plants the presence of $X f$ does not lead to any disease development or recognizable symptoms and are often referred to as symptomless host plants (Raju et al. 1983). They include species commonly found in riparian habitats, as well as a wide array of ornamental plants and weeds (Costa et al. 2004; Raju et al. 1983). Tests in the 1940's identified 91 of 116 tested plant species as hosts of $X f$, then known as "Pierce's Disease Virus" (Freitag 1951). In some, the species the bacteria remain localized, non-pathogenic, and non-symptomatic, propagating in small sections of the plant. In others, the bacteria multiply and spread systemically throughout the xylem tissue and usually do not become pathogenic (Fry et al. 1988). A third type of $X f$ reservoir (i.e. cultivated grape, Vitis vinifera) is the pathogenic host, where a systemic or localized cell buildup causes the symptomatic expression of Pierce's Disease and eventually kills the plant (Goodwin et al. 1992).

Pierce's Disease Development and Symptoms. Fundamental to combating a disease is to know how it develops. $X f$ is characteristically observed embedded in an extracellular translucent matrix within the cell walls of xylem vessels (Lindow 2001). Where cells colonize a vessel, they usually develop into large masses causing plugging (Hopkins et al. 1973). Vascular gels may be generated as part of the vine response to infection and also contribute to xylem vessel blockage (VanderMolen et al. 1983). In susceptible grapevines, the build up of bacterial cells in the xylem tissue causes increased water stress to the upper regions of the plant (Goodwin et al. 1988; Hopkins 1983). In early phases of the disease, water can still move through the vines via a tortuous path, but eventually, as enough of the vessels are blocked, the flow of water is reduced to below vine demand, leading to symptoms of water stress (Hopkins 1985). 
The first evidence of PD infection usually is a drying or "scorching" of leaves. The leaves become slightly chlorotic along the margins before drying, or the outer edge of a leaf may dry suddenly while still green. Often, scorched leaves dry down to the base of the blade and separate, leaving the petiole still attached to the cane (Goodwin et al. 1992). The woody portions of diseased canes are generally dry, especially on chronically infected vines. The bark on such canes matures irregularly. Mature canes may have tan or brown bark interspersed with islands of green immature tissue, and immature green canes may have areas of mature brown bark (Hopkins et al. 2002). About mid-growing season, when foliar scorching begins, some or all of the fruit clusters may wilt and dry up or portions of clusters may dry up at any time following fruit set. Permanently PD infected grapevines die in the first two or three years after infection (Goodwin et al. 1992).

Sharpshooters: Insect Vectors of Xylella fastidiosa. PD is transmitted by sharpshooters, which are insects in the Family Cicadellidae, subfamily Cicadellinae, and tribe Proconiini. When a sharpshooter feeds on plant xylem tissue containing $X f$, bacteria are ingested and attach to the insect's mouthparts. When the sharpshooter moves to another plant and resumes feeding, some of the bacteria may dislodge and are injected into the plant. In this manner, bacteria are moved from plant to plant (Hill et al. 1995). Sharpshooters native to California associated with $X f$ include the green sharpshooter (GSS, Draeculacephala minerva) (Ball), red-headed sharpshooter (RHSS, Carneocephala fulgida) (Nottingham) and blue-green sharpshooter (BGSS, Graphocephala atropunctata) (Signoret) (Hewitt et al. 1942; Purcell et al. 1985). 
Several variables involving insect vectors play a role in PD expression, including population density, host feeding preference and feeding behavior. Where the reservoir of infected host plants is not concentrated near grapevines and the population density of sharpshooters remains low, PD remains a localized problem (Purcell et al. 1999a).

Most plant feeding insects do not feed on xylem sap because it is primarily water and almost devoid of nutrients (Brodbeck et al. 1992). Due to the limited number of xylem feeders, only a small number of species are capable of transmitting PD (Frazier 1943). The leafhoppers (sharpshooters) and spittlebugs are capable of sustaining themselves on xylem fluid, and are known vectors of PD (DeLong et al. 1950). The relatively low concentrations of nutrients in the xylem, compared to phloem, require extremely high daily feeding rates for sharpshooters (100-300 times dry body weight per day) (Turner et al. 1959), possibly allowing for a greater frequency of feeding on $X f$ infected host plant tissue (Hill et al. 1995).

Sharpshooters seem more likely to acquire $X f$ from a host plant systemically infected with bacteria than one in which the bacteria remain localized (Raju et al. 1983). On systemically infected host plants, there is a greater chance the sharpshooter will feed upon infected tissue because of the bacteria's movement through the plant (Fry et al. 1988). Once they acquire $X f$, adult sharpshooters can remain infected for life. Immature sharpshooter nymphs lose the ability to transmit $X f$ once they shed their cuticle, which includes the mouthparts. They can regain their infectious capabilities as soon as they feed on infected tissue (Hill et al. 1995).

Most PD infections from blue-green, green and red-headed sharpshooters are a result of springtime feedings by over wintering adult sharpshooters (Feil et al. 2003). 
The incidence of PD seems to be greatest in areas adjacent to riparian, grass pasture and other over wintering habitats, and declines with increased distance from those locations. Most PD symptoms occur within 300 feet of the $X f$ reservoirs (Purcell 1974).

Native sharpshooters are often widely distributed throughout vineyards in the late summer and fall, but most late summer infections do not result in PD because the insects feed on young tissue that is soon pruned off (Feil et al. 2003; Purcell 1976). Late-season infections can be serious in young vines because less wood is pruned from them, leaving infected tissue on the vine (Purcell 1981).

PD has become more prevalent in California over the past decade with the introduction of a more efficient vector, the glassy-winged sharpshooter (GWSS, Homalodisca coagulata) (Purcell et al. 1999a.). GWSS was first detected in California in 1994, most likely imported from the southeastern United States as eggs on nursery stock (Sorenson et al. 1996). In contrast to native sharpshooters, the glassy-winged sharpshooter is more likely to transmit $X f$ during late season feeding. Its large size allows its stylets to penetrate hard tissue, and it can feed much lower on the vine's trunk, therefore, infecting all parts above the inoculation point (Feil et al. 2003). The presence of the pathogen lower in the vine's mature wood requires severe pruning or vine removal to prevent a sustained PD infection.

The GWSS is native to the New World, and has a natural distribution from the Southeastern U.S., north to Wisconsin and west to northern Mexico (Young 1958). The GWSS feeds on a variety of native, ornamental and crop plants, and in the process transmits $X f$, which is the casual agent of several diseases of other agronomic, horticultural and ornamental plants in California (Blua et al. 1999). The GWSS has an 
extremely broad host range, feeding on over 70 host plants, representing over 30 families (Raju et al. 1983). Favorite woody plants include oak, ash, silk tree, crape myrtle, and peach (Turner et al. 1959), whereas favored herbaceous varieties include sunflower, hollyhock, okra, lambs quarters, cotton, corn, and snow peas.

History of Pierce's Disease in California. PD has been recognized as a serious, but geographically limited, disease of grapes in California for over 100 years (Raju et al. 1983). Newton Pierce first described $X f$ infection in grapes (Pierce 1892). He was a scientist sent by the U.S. Bureau of Agriculture to investigate the heavy loss of vineyard acreage in southern California during the 1800s. Pierce described the affliction first observed near Anaheim during the year 1884 as "California Disease" or "Anaheim Disease," which by 1895 PD was responsible for the destruction of 35,000 acres of productive southern California vineyards (Gardner et al.1974). Three major epidemics occurred in California in the early to mid twentieth century: Santa Clara Valley between 1914 and 1918, San Joaquin and Napa Valleys between 1935 and 1940 and again in Napa Valley between 1960 and 1962 (Gardner et al. 1974).

Pierce hypothesized that bacterial isolates from diseased vines could be the causal agent of disease (Pierce 1892). However, until the mid twentieth century, PD was believed caused by a virus because no bacterial or fungal pathogens were identified and it was known to be transmitted by grafting and vectored by insects (Hewitt et al. 1942). With electron micrograph images of the pathogen in xylem elements (Hopkins et al. 1973; Goheen et al. 1973) the pathogen was identified as bacterial, and Davis et al. (1978) isolated proved that $X f$ was the causal agent of PD. 
PD has historically affected only a few well defined regions in California (Hopkins et al. 2002). In northern California, Pierce's Disease normally occurs only in localized areas and is generally limited to an "edge effect" pattern in vineyards near riparian areas (Purcell 1975). Riparian corridors often contain all the factors needed for PD to develop and have chronic epidemics (Blua et al. 2001). Many common riparian plant species in California are identified as hosts for the bacterium (Raju et al. 1980) and abundance of sharpshooter vectors tends to be greater in vineyards adjacent to riparian corridors.

During the 1990s, the glassy-winged sharpshooter became established in virtually every southern California County. GWSS has now been trapped in over a dozen Central Valley and north coast counties (Blua et al. 1999). In southern California the introduced glassy-winged sharpshooter has become established as a devastatingly efficient PD vector, causing severe damage to regional wine grapes (Blua et al. 1999; Purcell et al. 1999a). This has led to major outbreaks of the disease in areas such as the Temecula Valley, and it poses an immediate threat to the rest of the state's grape growing regions (Blua et al. 1999; Sorenson et al. 1996). 


\section{MATERIALS AND METHODS}

Field data were collected for two growing seasons, 2002-2003. Forty-five environmental variables were measured, ranging from soil chemistry to climate. The data were collected from eight commercial vineyards, located in northern and southern California (Table 1).

Soil analysis. We sampled soil from each of the field sites using a $7 \mathrm{~cm}$ soilcoring auger, taking an approximate $500 \mathrm{~cm} 3$ sample from $0.5 \mathrm{~m}, 0.67 \mathrm{~m}$ and $1 \mathrm{~m}$ depths, and pooling the samples. Several samples were randomly taken from each vineyard block for a total of about $2 \mathrm{~kg}$ of soil. Samples were analyzed for $\mathrm{pH}$, base saturation, the macronutrients nitrogen, phosphorus, potassium, sodium, calcium, magnesium, and sulfur, and the micronutrients manganese, boron, zinc, aluminum, iron, and cobalt (Table 7).

Soil samples were prepared and analyzed using the laboratory procedures of Dr. Thomas A. Ruehr (Earth and Soil Sciences Department, Cal Poly State University San Luis Obispo, Methods of Analysis for Soil Samples 2003). Soil moisture content was determined using a forced draft oven set at $105^{\circ} \mathrm{C}$ for 48 hours. The moisture content was determined on an oven dry mass basis. This value was used to correct the moist weight of the samples used.

Soil $\mathrm{pH}$ was determined using the method of Thomas (1996), mixing the soil sample with $0.01 \mathrm{M}$ calcium chloride in a 2:1 solution: soil ratio. The $\mathrm{pH}$ meter was adjusted to $\mathrm{pH} 7.00$ with a standard buffer solution. A combination glass electrode (Orion Research Inc., Model 201 Digital pH Meter with Probe) was used to read the soil $\mathrm{pH}$. 
The electrical conductivity (EC) of the soil solution was determined using the method of Rhoades (1996). About 200 grams of soil were mixed carefully with distilled water until the soil attained a glistening condition on the surface. The soil suspension was covered with cellophane for one hour, and then soil solution was extracted under vacuum. The resulting soil solution was read using a conductivity meter (Orion Research Inc., Model 101 Conductivity Meter), in units of decisiemens per meter (dS/m), which is equivalent to millimhos/cm (mmhos/cm).

Exchangeable cations (calcium, magnesium, potassium and sodium) were determined using the methods of Helmke et al. (1996) and Suarez (1996). A $10 \mathrm{~g}$ soil sample was shaken with $100 \mathrm{ml}$ of ammonium neutral normal acetate for 5 minutes. The solution was filtered. Ten $\mathrm{ml}$ of this extract was diluted to $500 \mathrm{ml}$ with deionized water. The solution was ran on an atomic absorption spectrophotometer (Model 460, PerkinElmer, Waltham, Mass.). Calcium and magnesium were done in the absorption mode with calcium and magnesium lamps. Potassium and sodium were analyzed in the emission mode. The values were reported as parts per million of each cation on the soil cation exchange sites.

Cation Exchange Capacity (CEC) was determined by summing the values for the exchangeable basic cations of calcium, magnesium, potassium and sodium. This is valid for soils with a $\mathrm{pH}$ of approximately 6.8 and higher. Also, as long as the electrical conductivity (EC) of the soil is below about $2 \mathrm{dS} / \mathrm{m}$, this summation provides a good approximation of the true CEC of the soil (Sumner et al. 1996).

Sulfate-sulfur was determined on the same sample used to measure the exchangeable cations (Tabatabai 1996). A $10 \mathrm{ml}$ aliquot of the filtered soil extract was 
treated with 0.1 grams of barium chloride crystals. After one minute the solution was thoroughly stirred and the amount of transmittance in the suspension was determined with a colorimeter set at 420 nanometers wavelength. Ammonium acetate extracting solution was set at $100 \%$ transmittance.

Micronutrient metal cations were evaluated using the methods of Loeppert et al. (1996); Grambell (1996); Reed et al. (1996); Sims (1996) and Amacher (1996). A 20 gram soil sample was mixed with $40 \mathrm{ml}$ of $0.005 \mathrm{M}$ DTPA chelate (DiethyleneTriaminePentaAcetic acid) solution at $\mathrm{pH}$ 7.30. This suspension was shaken on a reciprocating shaker for two hours and then filtered. The extract was analyzed on the atomic absorption spectrophotometer. Each element was analyzed using the absorption mode with a separate lamp for each element. The values for each element were reported in parts per million of each extractable (and plant available) element in the dry soil. Iron, manganese, copper, zinc, and nickel were evaluated along with cobalt (due to its importance in nitrogen fixing legumes supporting microbial growth of the nitrogen fixing bacteria).

Plant available phosphorus was determined using the methods of Kuo (1996). A 20 gram soil sample was mixed with $100 \mathrm{ml}$ of $0.5 \mathrm{M}$ sodium bicarbonate and shaken for 30 minutes in the presence of activated charcoal. Then, $35 \mathrm{ml}$ of the filtered solution was reacted with an acidified mixture of hydrochloric acid, ammonium molybdate and ammonium vanadate. The color was allowed to develop for 10 minutes. The percentage of light transmittance was determined using a colorimeter set at 420 nanometers against a sodium bicarbonate blank solution (set at $100 \%$ ). The values were compared to a 
standard curve and reported as parts per million of extractable (and plant available) phosphorus in the dry soil.

Ammonium-N and nitrate-N were determined using the methods of Mulvaney (1996). A 20 gram sample of soil was shaken with $100 \mathrm{ml}$ of $0.5 \mathrm{M}$ potassium sulfate solution. The nitrate was measured with a nitrate specific ion electrode. The ammonium was measured with an ammonium specific ion electrode. Both measurements were compared to values from a standard curve. The total inorganic nitrogen in the soil was reported as the parts per million of inorganic nitrogen in the dry soil.

Alternate host vegetation and grapevine sampling. Representative plant population samples were collected and identified from vegetation types in and around the vineyard sites. Samples were taken during the early season (May- June) and late season (August-September). Vegetation sampling for $X$. fastidiosa detection occurred on the dates listed from adjacent citrus groves, natural riparian and woodland habitats, and from weedy vegetation within the vineyard (Table 10). Samples were cooled, transported to the laboratory and stored at $-80^{\circ} \mathrm{C}$ to be tested for the presence $X f$.

Polymerase chain reaction (PCR) was relied on for identification of alternative host vegetation and verification of grapevine disease. Incidence of grapevine PD (Table 2) at each field site was determined by visual observation of PD symptoms in mid- to late season (July to September); and PCR analysis to verify disease presence of visually symptomatic vines.

PCR is a biochemical assay which identifies host plant reservoirs of $X$. fastidiosa as well as grapevine infections (Minsavage et al. 1994). Recent advances in amplification of pathogen-specific DNA sequences by PCR have allowed for highly 
sensitive detection of disease within their plant host (Minsavage et al. 1994). The PCR procedure for the detection of $X$. fastidiosa was shown to be 100 -fold more sensitive than ELISA when using the RST 31 and RST 33 primer set which indicates the presence of disease in our vegetation sample by a 733-bp region when ran on an electrophoresis gel (Figure 6)(Minsavage et al. 1994).

DNA amplification and Polymerase Chain Reaction (PCR). We used the protocol for isolation of DNA from plant tissue for detection of $X$. fastidiosa with the DNeasy® Plant Mini Kit (Qiagen, Valencia, CA) with modifications from Dr. Heather Costa of UC Riverside. We ground a 2-3 cm piece of petiole in an Agdia (Elkhart, IN) mesh sample bag with 500 ul 1x PBS. We then transfered 100 ul to a $1.5 \mathrm{ml}$ microcentrifuge tube. We then added $400 \mathrm{ul}$ of Buffer AP1 and $4 \mathrm{ul}$ of RNase A stock $(100 \mathrm{mg} / \mathrm{ml})$ to the microcentrifuge tube. We incubated the mixture for $10 \mathrm{~min}$. at $65^{\circ} \mathrm{C}$, and mix 2-3 times during incubation by inverting the tube.

We then added 130 ul of Buffer AP2 to the lysate, mix, and incubated for 5 minutes on ice. We applied the lysate to the QIAshredder spin column sitting in a $2 \mathrm{ml}$ collection tube and centrifuged for 2 min at maximum speed. We transferred the flowthrough fraction to a new tube without disturbing the pellet. We then added 1.5 volumes of Buffer AP3/E to the cleared lysate and mixed by pipetting. We then applied $650 \mathrm{ul}$ of the mixture, including any precipitate which may have formed, to the DNeasy® mini spin column sitting in a $2 \mathrm{ml}$ collection tube. We centrifuged for $1 \mathrm{~min}$ at $6000 \mathrm{~g}(8000 \mathrm{rpm})$ and discarded the flow through. We placed the DNeasy® column in a new $2 \mathrm{ml}$ collection tube, added 500 ul Buffer AW to the DNeasy® column and centrifuged for $1 \mathrm{~min}$ at $6000 \mathrm{~g}(8000 \mathrm{rpm})$. We discarded the flow-through and reused the collection 
tube. We then added 500 ul Buffer AW to the DNeasy® column and centrifuged for 2 min at maximum speed to dry the membrane. We then transferred the DNeasy® column to a $1.5 \mathrm{ml}$ microcentrifuge tube and pipetted $100 \mathrm{ul}$ of preheated $\left(65^{\circ} \mathrm{C}\right)$ Buffer $\mathrm{AE}$ directly onto the DNeasy® membrane. We incubated for $5 \mathrm{~min}$ at room temperature and then centrifuged for $1 \mathrm{~min}$ at $6000 \mathrm{~g}(8000 \mathrm{rpm})$ to elute. We repeated the elution.

We prepared the master mix equal to $18 \mathrm{ul}$ sterile ultrapure water and $1.0 \mathrm{ul}$ each of $10 \mathrm{uM}$ RST 31 and RST 33 primers (Sigma Genosys, The Woodlands, TX). We dispensed 20 ul master mix into each tube with a PCR Ready-To-Go® bead (Amersham Bioscience c/o GE Healthcare, Piscataway, NJ) and let it dissolve. We added 5 ul sample DNA to corresponding tube. We ran the program on the thermocycler with the settings below:

[ 35 cycles ]

$95.0 \quad\left[\begin{array}{lllll}94.0 & 55.0 & 72.0\end{array}\right] \quad 72.0 \quad 4.0$

$5: 00 \quad[0: 40 \quad 0: 40 \quad 1: 00] \quad 5: 00 \quad \infty$

We prepared $1 \%$ agarose gels with ethidium bromide incorporated into the gel. We poured pre-measured 0.2 grams of agarose into a $125 \mathrm{ml}$ Erlenmeyer flask and added $20 \mathrm{ml}$ of $1 \mathrm{x}$ TAE. We swirled and microwaved approximately 45 seconds or until the agarose crystals were fully dissolved. We added 2 ul of ethidium bromide (stock $=10$ $\mathrm{mg} / \mathrm{ml}$ ) and allowed it to cool before pouring the gel. We filled the gel box with 1x TAE when the gel and wells were ready, and prepared the samples for electrophoresis. We mixed $5 \mathrm{ul}$ of the PCR product with $2 \mathrm{ul}$ of loading dye and loaded it into the wells. We used a $100 \mathrm{bp}$ ladder at the same ratio of $5 \mathrm{ul}: 2 \mathrm{ul}$ to loading dye and PCR products. We ran the electrophoresis using a Mini-Sub Cell GT Cell (Bio Rad, Hercules, CA) at 85 
volts for 30-35 min before viewing the gel on the Gel Doc 2000 (Bio Rad, Hercules, CA) and saving the image (Figure 6).

Sharpshooter Monitoring. We used yellow sticky cards (Seabright, Emeryville, CA) to monitor sharpshooter population densities. Sticky cards are an effective technique to determine general population size and distribution for mobile insects. We marked each card with the date, site name, and card location. We placed cards in riparian zones (when present), on or near nearby ornamental vegetation, and at the end of vine rows at each site. The cards were placed at equal distant intervals (approximately 15 meters) so that the entire site could be effectively sampled. Cards were changed every two weeks, and sharpshooter counts were recorded per location (Table 1).

Vine Nutrient Status. Sampling took place according to the protocol of Christensen et al. (1978). Around bloom time in each study year, we took 60-80 petioles randomly from vines throughout each field site, dried them, and sent them to a commercial laboratory for analysis. We sampled at bloom time to attempt to get data from the vines at the same physiological stage, regardless of regional conditions. We took samples from the opposite side of a flower cluster, removed the leaf blade and placed the petiole in a paper bag for drying. Tissue samples were labeled and sent to Dellavalle Laboratories, Inc. (Fresno, CA) (Figure 7 and 8). Elemental analysis included nitrate-nitrogen, phosphorus, potassium, zinc, manganese, sodium, boron, calcium, magnesium, iron, and copper.

Vine Water Status. Vine water status was determined by use of a pressure bomb (PMS Co., Corvallis, OR). This tool is an industry standard and easy to operate. We tested midday stem water potential from about 11:00 to 14:00; this is the most accurate 
testing period, because it corresponds to the time of maximum plant water stress (maximum water deficit). Midday is also the time when weather conditions cause the maximum rate of water loss from the plant. The amount of pressure applied to a sample with the bomb that causes water droplets to appear at the cut end or the petiole estimates the degree of tension or water potential in the vine's vascular system. High pressure indicates a high amount of tension (low water potential) and a high degree of water stress. The units of pressure on the bomb were read in bars, and were converted to MegaPascals $(-1 \mathrm{MPa}=10$ bars $)($ Table 5$)$.

To estimate leaf water potential, we designated a set of at least 10 randomly selected vines within each vineyard block. We selected mature leaves that were fully exposed to the sun, and cut the petiole at a right angle as close to the cane as possible. Leaves were immediately placed in a plastic bag, the petiole then slid through the rubber gasket on the chamber lid and secured by screwing tight. The chamber was then slowly filled with pressurized gas, and a hand lens was focused on the tip of the petiole to look for bubbling, indicating when the negative pressure of those conductive cells is equalized and overcome.

Soil Moisture Monitoring. We used Watermark ${ }^{\circledR}$ sensors (Irrometer, Riverside, CA), which are modified gypsum blocks (electrical resistance blocks), which measure the electrical resistance of a solution and, subsequently, estimate soil moisture content. This device uses two electrodes embedded in gypsum or a granular material. As water dissolves the gypsum, calcium ions go into solution and act as a conductor between the electrodes; as the soil dries, resistance increases. Wires extending from the block to the soil surface are connected to a data logger which records the soil moisture fluctuations 
throughout the growing season. One data logger, three sensors, and one temperature probe were installed at each vineyard site.

Initially, we soaked the Watermark ${ }^{\circledR}$ sensors in water overnight. At each field site, we bored a hole with a soil auger, at different depths. We then connected the electrical wire extensions from the blocks into the data logger (M.K. Hansen Inc., Wenatchee, WA). We also installed a temperature probe at a depth of 24 inches. This was used to correct the readings for temperature differences. The data were recorded as centibars $(\mathrm{cB})$ of soil moisture tension, and downloaded from the data loggers at the end of the season in comma delineated formatting, which was entered into a computer spreadsheet, converted to metric MegaPascals (MPa) and averaged for use in Canonical Correspondence Analysis (Table 4).

Climactic Information. We gathered climatic data for the study sites using the CIMIS and UC IPM websites (Table 6).

Statistical Analysis. All the environmental and viticulture factors that were assessed during the data collection period were combined into a database and analyzed with Canonical Correspondence Analysis (Ter Braak 1986). CCA is an ordination technique used to arrange species and sites along linear combinations of the environmental variables. It can relate community variation with the environmental variation. The primary advantage of CCA over multiple regression methods is that many dependent and independent variables can be assessed simultaneously. Given the multidimensional nature of $\mathrm{PD}, \mathrm{CCA}$ can determine the most influential factors determining PD susceptibility and tolerance in vineyards. The computer program used to 
run CCA is called Canoco, a Fortran 77 program for canonical community ordination by correspondence analysis.

Having numerous sites in various locations throughout the state enables Canoco to evaluate all the conditions that are present at each vineyard and correspond it to the disease severity of that particular area. In doing so the statistical program can direct us to the variables which are found repeatedly at highly infected sites and therefore more research can be done to evaluate their significance in this multidimensional disease epidemic.

All data for environmental variables was transferred into a numerical format for the FORTRAN 77 program, Canoco, to generate a solutions file identifying the most significant variables associated with increased severity of Pierce's Disease. CCA requires that the data are in a specific file type called species composition data (Figure 10). The file must have a*.SPE extension for the file to be readable. The other specified file should be called environmental data (Figure 9). The extension required for that file is *.ENV. The analysis was run once the program recognized both data sets. The output has the extension *.SOL (Figure 11 and 12).

The coordinates from the Canoco *.SOL file are plotted in a graphical program to assess the significance of environmental variables affecting species composition (Figure 1). Graphical outputs from Canoco were used to determine positive and negative correlations between the environmental variables and increased PD severity (Tables 8 and 9). The relative position of environmental variables on the diagrams explains their significance in correlation of species distribution. The longer the length of arrow in the Canoco ordination diagram, the more strongly the variable coordinates with the variation 
in community and the angle between environmental vectors from the graphical Canoco outputs determines the positive or negative correlation between variables. 


\section{RESULTS}

Sharpshooter species and sticky trap totals for all vineyard locations were recorded in table 1. The glassy-winged sharpshooter and red-headed sharpshooter were present in southern California vineyard locations, whereas in northern California the blue-green and red-headed sharpshooters were found (Table 1). Guadagni vineyard had the highest sharpshooter counts while Cain vineyard had none present (Table 1).

Table 1. Total Sharpshooter Counts at Study Sites, 2002-2003.

\begin{tabular}{|l|l|c|c|c|}
\hline \multicolumn{1}{|c|}{ Locations } & Adjacent Vegetation & GWSS & BGSS & RHSS \\
\hline Guadagni - Northern California & Riparian & 0 & 138 & 100 \\
\hline Cain - Northern California & Oak Woodland & 0 & 0 & 0 \\
\hline Beringer - Northern California & Riparian & 0 & 46 & 0 \\
\hline Callaway 1 - Southern California & Citrus & 3 & 0 & 0 \\
\hline Callaway 2 - Southern California & Riparian & 0 & 0 & 4 \\
\hline Hofer - Southern California & Urban Landscape & 62 & 0 & 0 \\
\hline DeBerard - irrigated - Southern California & None & 16 & 0 & 0 \\
\hline DeBerard - non-irrigated - Southern California & None & 14 & 0 & 0 \\
\hline
\end{tabular}

Visually symptomatic vines of PD infection were recorded in table 2, identifying the severity of Pierce's disease at each vineyard location in this study. Sites in both northern and southern California had PD present (Table 2). The only two southern California vineyards, Hofer and DeBerard, to show a reduced amount of PD incidence were non-irrigated (Table 2). Guadagni was the only vineyard site in northern California with increased levels of PD (Table 2) and was associated with riparian adjacent vegetation (Table 1).

Table 2. Visually Symptomatic Incidence of PD at Study Sites.

\begin{tabular}{|l|c|c|c|}
\hline \multicolumn{1}{|c|}{ Location } & Total vines & Total Diseased & Incidence (\%) \\
\hline Guadagni & 500 & 118 & 23.7 \\
\hline Cain & 500 & 1 & 0.02 \\
\hline Beringer & 500 & 1 & 0.02 \\
\hline Callaway 1 & 1179 & 437 & 37.1 \\
\hline Callaway 2 & 1448 & 379 & 26.2 \\
\hline Hofer non-irrigated & 6056 & 333 & 5.5 \\
\hline
\end{tabular}




\begin{tabular}{|l|c|c|c|}
\hline DeBerard irrigated - None & 4021 & 1037 & 25.8 \\
\hline DeBerard non-irrigated - None & 3192 & 6 & 0.2 \\
\hline
\end{tabular}

We determined the frequency of $X f$ in vineyard vegetation acting as host plant bacterial reservoirs in table 3, from the list of plant species verified by PCR for presence of X. fastidiosa (Table 10)(Appendix). Table 10 lists our PCR analysis results for alternate vegetation samples from all vineyard study sites. From these results 46 species were identified as host plants of Xylella fastidiosa at an $86.5 \%$ incidence of total vegetation samples.

Table 3. PCR Verified Incidence of $X$. fastidiosa in Study Site Vegetation.

\begin{tabular}{|c|c|}
\hline Locations & Host Plant $\boldsymbol{X}$. fastidiosa frequency (\%) \\
\hline Guadagni & 69.4 \\
\hline Cain & 100 \\
\hline Beringer & 66.7 \\
\hline Callaway 1 & 83.3 \\
\hline Callaway 2 & 100 \\
\hline Hofer & 100 \\
\hline DeBerard (irrigated) & 86.6 \\
\hline DeBerard (non-irr.) & 86.6 \\
\hline
\end{tabular}

Table 4 shows the Watermark ${ }^{\circledR}$ soil moisture sensor data recorded for each project site. Southern California, non-irrigated, study sites Hofer and DeBerard showed the highest level of water tension in the soil (Table 4). Of the northern California sites, Cain had the highest level of water tension in the soil (Table 4).

Table 4. Soil Moisture Monitoring Data for Study Sites.

\begin{tabular}{|c|c|c|}
\hline Locations & Soil Moisture (cB) & Soil Moisture (MPa) \\
\hline Guadagni & 26 & 0.026 \\
\hline Cain & 39.3 & 0.039 \\
\hline Beringer & 18 & 0.018 \\
\hline Callaway 1 & 39.4 & 0.039 \\
\hline Callaway 2 & 32.3 & 0.032 \\
\hline Hofer & 50.6 & 0.050 \\
\hline
\end{tabular}




\begin{tabular}{|c|c|c|}
\hline DeBerard (irrigated) & 19 & 0.019 \\
\hline DeBerard (non-irr.) & 50.5 & 0.051 \\
\hline
\end{tabular}

Vine water status at all study sites for 2002-2003 was averaged in table 5 for use in CCA. Cain vineyard had the highest degree of vine water stress throughout the growing seasons (Table 5).

Table 5. Vine Water Status Determined by PMS Pressure Bomb at Study Sites.

\begin{tabular}{|c|c|c|}
\hline Locations & Vine Water Status (Bars) & Vine Water Status (MPa) \\
\hline Guadagni & 13.3 & 1.33 \\
\hline Cain & 15.3 & 1.53 \\
\hline Beringer & 13.8 & 1.38 \\
\hline Callaway 1 & 13.9 & 1.39 \\
\hline Callaway 2 & 12.2 & 1.22 \\
\hline Hofer & 10.5 & 1.05 \\
\hline DeBerard (irrigated) & 11.9 & 1.19 \\
\hline DeBerard (non-irrigated) & 13.4 & 1.34 \\
\hline
\end{tabular}

Weather data for each study site was recorded in table 6. Average high and low temperatures and extreme high and low temperatures, along with daily precipitation were recorded from CIMIS and UC IPM websites to determine significance with CCA. The southern California vineyard sites are associated with less rainfall and warmer climatic conditions than the northern California locations. Guadagni, located in northern California, had the highest level of precipitation while Callaway had the lowest (Table 6).

Table 6. CIMIS Weather Data for Study Sites.

\begin{tabular}{|c|c|c|c|c|}
\hline Locations & Avg. high $\left({ }^{\circ} \mathbf{C}\right)$ & Avg. low $\left({ }^{\circ} \mathbf{C}\right)$ & Extreme low $\left({ }^{\circ} \mathbf{C}\right)$ & Avg. daily preciptation $(\mathbf{m m})$ \\
\hline Guadagni & 23.4 & 8.43 & -5.6 & 3.328 \\
\hline Cain & 25.2 & 10.56 & -4.25 & 1.3 \\
\hline Beringer & 25.2 & 10.56 & -4.25 & 1.3 \\
\hline Callaway 1 & 24.9 & 11.4 & -5 & 0.594 \\
\hline Callaway 2 & 24.9 & 11.4 & -5 & 1.104 \\
\hline Hofer & 26 & 10.7 & -3.3 & 1.104 \\
\hline $\begin{array}{c}\text { DeBerard } \\
\text { irrigated) }\end{array}$ & 26 & 10.7 & -3.3 & 1.104 \\
\hline $\begin{array}{c}\text { DeBerard (non- } \\
\text { irrigated) }\end{array}$ & 26 & 10.7 & -3.3 & \\
\hline
\end{tabular}


Recorded in table 7 are the vineyard study site soil analyses for 2002-2003.

Values for soil characteristics and soil nutritional elements are in table 7. This analysis was further used to produce CCA results correlating environmental variable with increased PD incidence.

The petiole tissue analysis data from samples sent to Dellavalle Laboratories, Inc.

(Fresno, CA) are included in figures 7 and 8 (Appendix). The petiole nutritional elemental analysis included nitrate-nitrogen, phosphorus, potassium, zinc, manganese, sodium, boron, calcium, magnesium, iron, and copper.

Table 7. Soil Analysis for Study Sites.

\begin{tabular}{|c|c|c|c|c|c|c|c|c|c|c|c|c|c|c|c|c|c|}
\hline Locations & Year & pH & $\mathbf{P}$ & $\mathbf{F e}$ & $\mathbf{Z n}$ & Mn & $\mathbf{C u}$ & Co & $\mathrm{Ni}$ & $\mathrm{Na}$ & $\mathbf{K}$ & Mg & $\mathbf{C a}$ & Sulfur & Salinity & Water & CEC \\
\hline Guadagni & 2002 & 7.9 & 31.1 & 10.6 & 0.3 & 4.1 & 0.8 & 0.2 & 1.5 & 52.0 & 58.6 & 426.3 & 3493.8 & 1.8 & 0.7 & 30.9 & 13.3 \\
\hline Guadagni & 2003 & 7.5 & 6.8 & 13.8 & 0.2 & 6.2 & 1.3 & 0.3 & 2.8 & 48.7 & 56.3 & 1023.8 & 2498.8 & 1.0 & 0.4 & 31.5 & 14.6 \\
\hline Cain & 2002 & 6.8 & 31.3 & 10.1 & 0.2 & 6.5 & 1.0 & 0.1 & 0.5 & 47.2 & 130.0 & 176.3 & 1161.3 & 1.5 & 0.5 & 27.8 & 7.8 \\
\hline Cain & 2003 & 6.4 & 11.5 & 8.4 & 0.4 & 10.0 & 0.8 & 0.1 & 0.5 & 57.2 & 146.5 & 165.0 & 1179.2 & 1.6 & 0.3 & 26.2 & 7.9 \\
\hline Beringer & 2002 & 7.0 & 5.2 & 9.9 & 0.4 & 3.4 & 0.2 & 0.2 & 0.5 & 47.5 & 55.7 & 317.5 & 1691.3 & 2.5 & 1.3 & 31.0 & 11.4 \\
\hline Beringer & 2003 & 5.7 & 10.3 & 10.8 & 0.3 & 12.2 & 0.2 & 0.2 & 0.5 & 101.3 & 42.6 & 240.0 & 1202.5 & 5.2 & 1.1 & 36.6 & 8.5 \\
\hline Callaway 1 & 2002 & 6.7 & 21.5 & 52.6 & 1.3 & 13.9 & 4.4 & 0.3 & 8.0 & 57.6 & 1401.3 & 353.8 & 1321.3 & 2.1 & 1.2 & 29.4 & 21.3 \\
\hline Callaway 1 & 2003 & 6.9 & 10.5 & 41.5 & 0.5 & 9.3 & 2.5 & 0.2 & 8.5 & 45.4 & 1127.5 & 406.3 & 977.5 & 1.6 & 0.8 & 30.6 & 21.3 \\
\hline Callaway 2 & 2002 & 6.7 & 21.5 & 9.5 & 0.9 & 9.9 & 1.1 & 0.1 & 0.3 & 127.5 & 53.5 & 324.2 & 1326.0 & 84.0 & 1.2 & 29.4 & 21.3 \\
\hline Callaway 2 & 2003 & 6.9 & 10.5 & 9.5 & 0.9 & 9.9 & 1.1 & 0.1 & 0.3 & 127.5 & 53.5 & 324.2 & 1326.0 & 84.0 & 0.8 & 30.6 & 21.3 \\
\hline Hofer & 2002 & 7.2 & 12.4 & 9.0 & 1.0 & 5.0 & 0.9 & 0.1 & 0.5 & 48.1 & 53.0 & 165.0 & 2022.5 & 13.7 & 0.4 & 24.9 & 11.8 \\
\hline Hofer & 2003 & 7.1 & 3.7 & 4.1 & 0.3 & 3.9 & 0.4 & 0.1 & 0.6 & 51.2 & 40.9 & 140.0 & 1865.0 & 7.6 & 0.4 & 21.5 & 10.8 \\
\hline DeBerard (irr.) & 2002 & 5.7 & 50 & 28.7 & 1.7 & 4 & 1.5 & 0.2 & 0.2 & 66 & 72.5 & 58.5 & 399.5 & 10.5 & 0.4 & 23.2 & 10.1 \\
\hline DeBerard (irr.) & 2003 & 5.7 & 50 & 28.7 & 1.7 & 4 & 1.5 & 0.2 & 0.2 & 66 & 72.5 & 58.5 & 399.5 & 10.5 & 0.4 & 23.2 & 10.1 \\
\hline DeBerard (non-irr.) & 2002 & 5.2 & 46.3 & 34.1 & 2 & 4.45 & 1.4 & 0.2 & 0.3 & 61.5 & 82.5 & 49.5 & 323.5 & 10.5 & 0.4 & 23.2 & 10.1 \\
\hline DeBerard (non-irr.) & 2003 & 5.2 & 46.3 & 34.1 & 2 & 4.45 & 1.4 & 0.2 & 0.3 & 61.5 & 82.5 & 49.5 & 323.5 & 10.5 & 0.4 & 23.2 & 10.1 \\
\hline
\end{tabular}

The canonical correspondence analysis multivariate ordination diagram determined from Canoco solution files assesses the interactions and mechanisms affecting species composition at the vineyard study sites (Figure 1). Figure 1 shows both positive and negative correlating vineyard factors that contribute to our species composition at the study sites. 


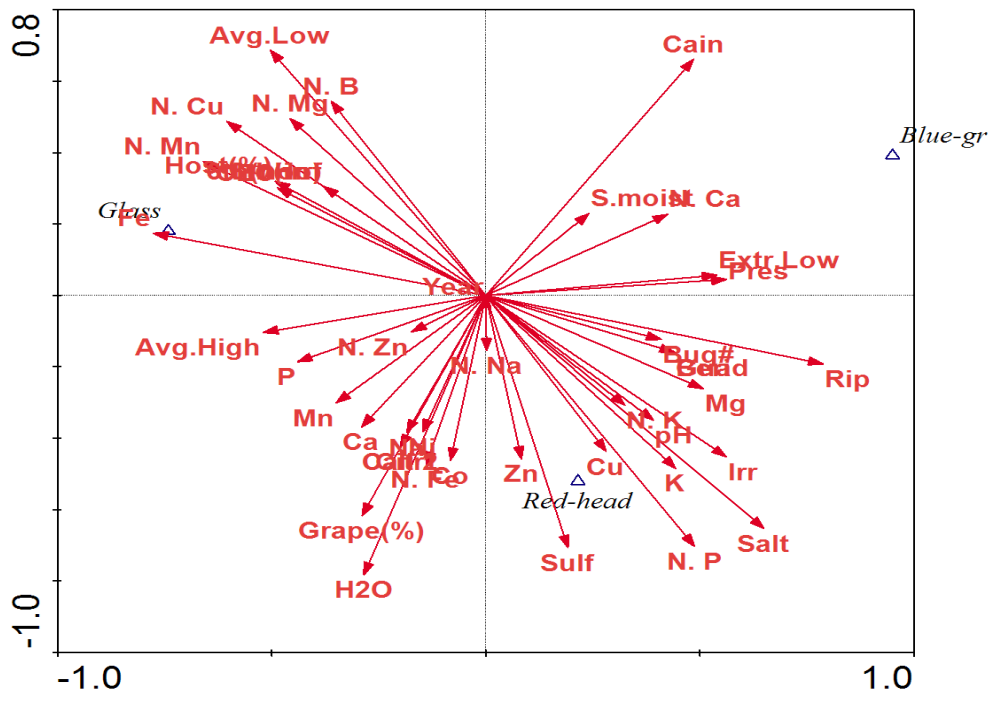

Figure 1. Graphical Output from Canoco Correspondence Analysis.

Correspondence of increased host plant $X f$ presence with increased frequency of PD was not demonstrated by CCA ordination diagrams (Figure 2). There was not a relationship with alternate vegetation containing $X f$ and the incidence of PD within the vineyard site (Figure 2). The red-headed and glassy-winged sharpshooters are positively correlated vectors of PD in our study locations (Figure 2). The blue-green sharpshooter did not correlate with increased incidence of PD.

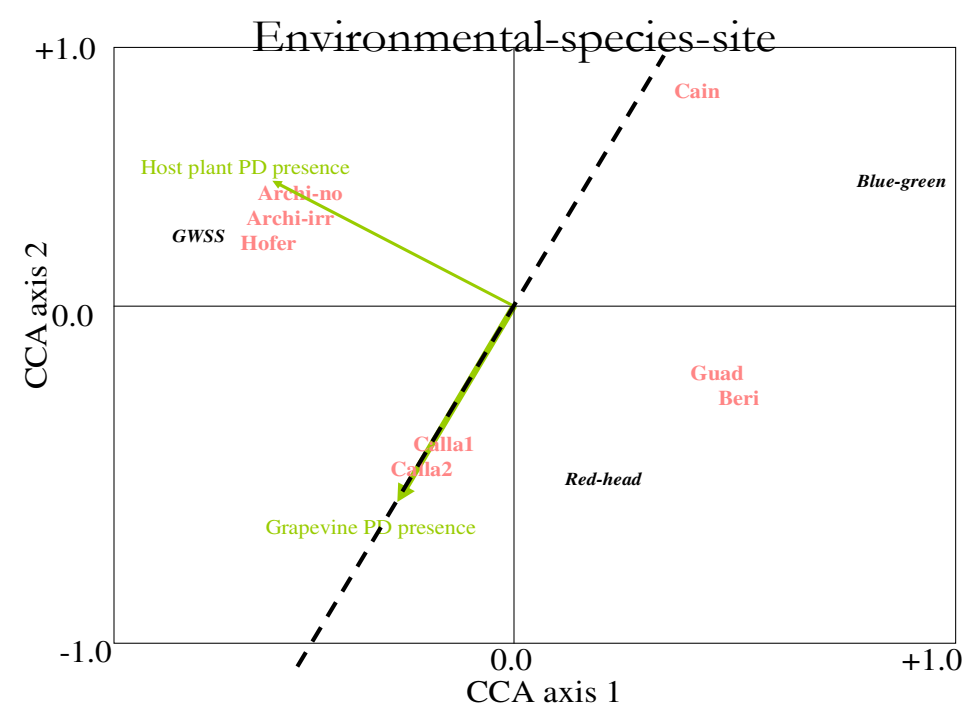

Figure 2. PD Severity and Host Plant Correspondence with Study Site. 
Canonical correspondence analysis of the petiole and soil nutritional levels identified increased vine petiole calcium and vine petiole magnesium levels as the most antagonistic nutrient variables for an increased PD severity in California grapevines (Figure 3). Increased levels of petiole iron, petiole phosphorus and soil sulfur were identified as the most significant nutritional elements promoting increased disease incidence (Figure 3).

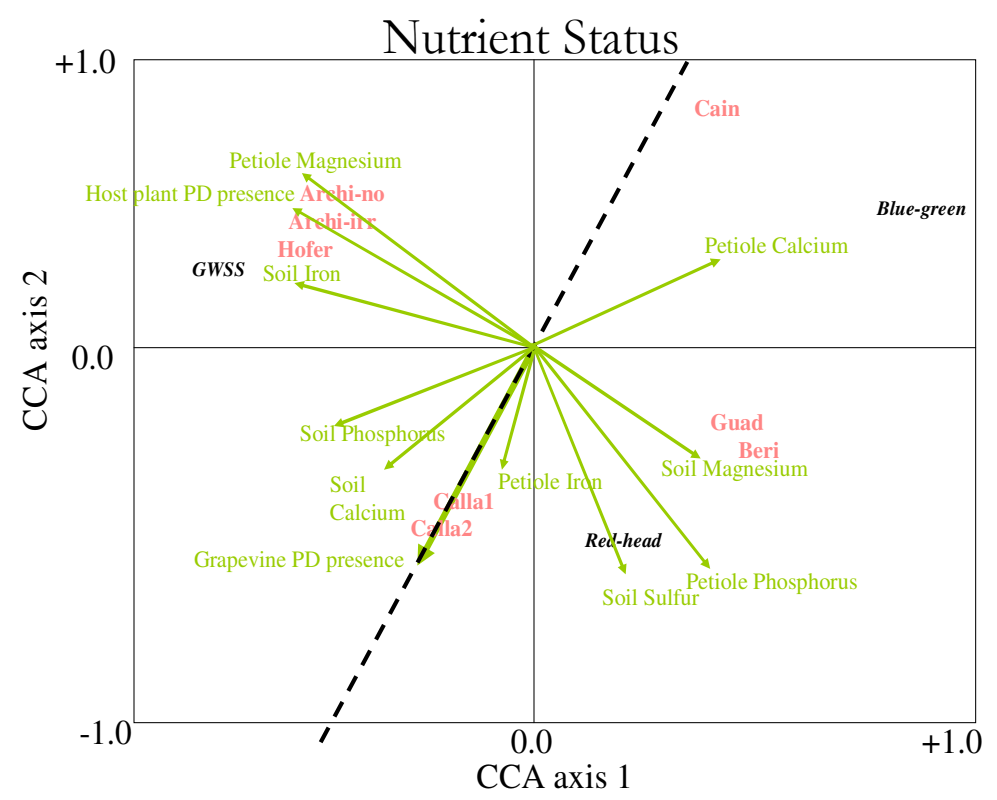

Figure 3. PD Severity Correspondence of Vine and Soil Nutrient Status.

The most significant environmental variables of climate and habitat which correspond with an increased frequency of PD in grapevine are increased soil moisture and adjacent citrus farming (Figure 4). Alternatively, the most conversely correlating climate and habitat characteristics are average low temperature and increased soil dryness (Figure 4). 


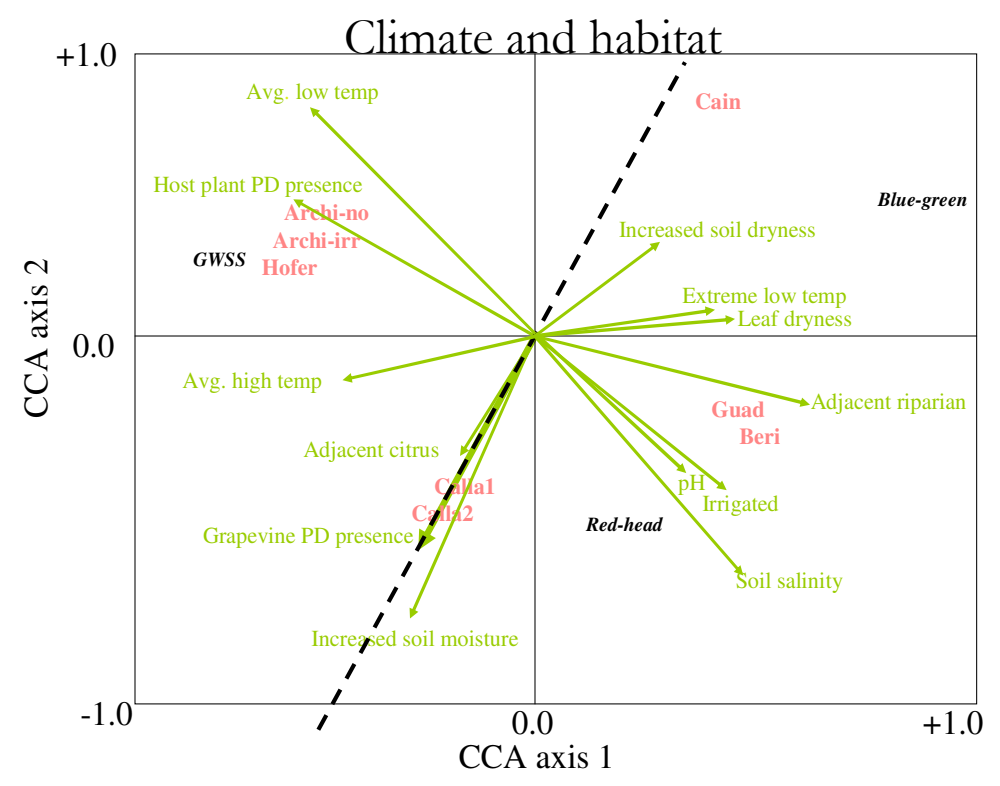

Figure 4. PD Severity Correspondence of Climate and Habitat.

Adjacent riparian habitat negatively correlates with GWSS species distribution (Figure 5), however, blue-green and red-headed sharpshooter species are associated with adjacent riparian corridors at vineyard locations (Figure 5). GWSS is predicted to be present more often in the agricultural-urban interface of the Cucamonga Valley in southern California, followed by the Temecula Valley sites and least in northern California (Figure 5).

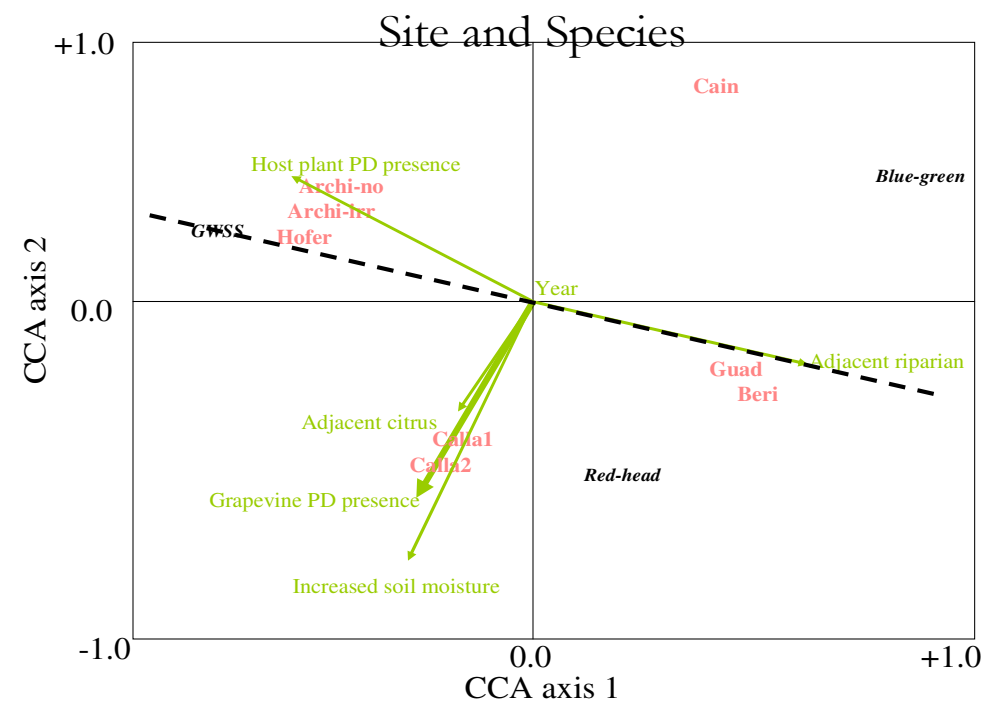

Figure 5. Study Site Location Correspondence of Sharpshooter Species. 
The correlation of each vineyard environmental variable with an increased incidence of PD as interpreted from Canoco diagrams and PD solution files are listed in table 8 and 9 . Of the 24 environmental variables with a positive correlation to increased PD presence, increased soil moisture was identified by CCA as most significant (Table 8). Increased levels of several vine and soil nutrients positively correlated with increased PD at our study sites (Table 8).

Table 8. Positive Correlating Variables to Increased PD Incidence.

\begin{tabular}{|c|c|}
\hline Positive Correlation & Variable \\
\hline 1 & $\mathrm{H} 2 \mathrm{O}$ - Increased soil moisture \\
\hline 2 & Sulf - Soil sulfur content \\
\hline 3 & N. Fe - Vines iron content \\
\hline 4 & N. P - Vines phosphorus content \\
\hline 5 & Citr - Adjacent Citrus \\
\hline 6 & $\mathrm{Na}$ - Soil sodium content \\
\hline 7 & Co - Soil cobalt content \\
\hline 8 & $\mathrm{Ni}$ - Soil nickle content \\
\hline 9 & $\mathrm{Ca}$ - Soil calcium content \\
\hline 10 & Mn - Soil manganese content \\
\hline 11 & $\mathrm{Zn}$ - Soil zinc content \\
\hline 12 & P - Soil phosphorus content \\
\hline 13 & Salt - Soil salinity \\
\hline 14 & Avg. High - 10 year avg. high temp. \\
\hline 15 & $\mathrm{Cu}$ - Soil copper content \\
\hline 16 & K - Soil potassium content \\
\hline 17 & Irr- Irrigation presence \\
\hline 18 & $\mathrm{pH}$ - Soil pH level \\
\hline 19 & N. Zn - Vines zinc content \\
\hline 20 & N. K - Vines potassium content \\
\hline 21 & N. Na - Vines sodium content \\
\hline 22 & Mg - Soil magnesium content \\
\hline 23 & Bug \# - Sharpshooter counts \\
\hline 24 & Rip - Adjacent riparian \\
\hline
\end{tabular}

Twelve environmental variables were identified by CCA as negatively correlating to PD development (Table 9). Increased levels of five grapevine nutrients; calcium, 
boron, magnesium, copper and manganese are correlated with less occurrence of PD in our study sites (Table 9). We found a negative correlation from CCA in climate and habitat characteristics of average low temperature and low plant and soil moisture status (Table 9).

Table 9. Negative Correlating Variables to Increased PD Incidence.

\begin{tabular}{|c|c|}
\hline Negative Correlation & Variable \\
\hline 1 & Avg. Low - 10 year avg. low temp. \\
\hline 2 & N. Ca - Vines calcium content \\
\hline 3 & N. B - Vines boron content \\
\hline 4 & S. moist - Increased Soil Dryness \\
\hline 5 & N. Mg - Vines magnesium content \\
\hline 6 & Extr. Low - 10 year extreme low \\
\hline 7 & Pres - Leaf dryness (Pressure bomb) \\
\hline 8 & N. Cu - Vines copper content \\
\hline 9 & Host \% - Host plant PD presence \\
\hline 10 & CEC - Soil cation exchange capacity \\
\hline 11 & N. Mn - Vines manganese content \\
\hline 12 & Fe - Soil iron content \\
\hline
\end{tabular}




\section{DISCUSSION}

Canonical correspondence analysis is best utilized on complex ecosystems for exploratory purposes to identify significant environmental factors contributing to variation in species composition. As demonstrated by CCA in this project moist and warm climatic conditions favor conditions promoting an increased frequency of Pierce's Disease in grapevines. It is likely climate, particularly temperature and humidity, will limit the distribution and abundance of all organisms associated with PD. Of the 24 positively correlating variables, increased soil moisture and high daily temperatures are identified as leading causes for increased presence of Pierce's Disease within a vineyard location. Increased soil moisture promoted PD occurrence, as identified by CCA, while low soil moisture and low plant water status are shown to inhibit disease development. Abundance of water in the soil allows for minimal grapevine stress, possibly making it a better target for plant feeding insect species.

Aspects of irrigation management like vine water status might play a role in sharpshooter preference. The reduced availability of water in the soil for the grapevine will increase water stress of the plant. Since sharpshooters are totally dependent on plant water status availability, it is likely the occurrence of PD would be more prevalent where the vines are not water stressed and vector visits are frequent. Water stress of the vines

may diminish the presence of PD; however, the vine quality may suffer due to lack of water. The non-irrigated locations of southern California, DeBerard and Hofer, demonstrated the inhibition of widespread PD which differed from adjacent irrigated areas with significant symptomatic and dead vines. The two sites had the least amount of 
PD presence in all of southern California. However, due to the inconsistencies with crop quality I would not recommend non-irrigated practices to avoid PD infection.

Differences in disease expression may depend on soil types. Reasons for disease expression might be biological or abiotic factors such as nutrient balance or $\mathrm{pH}$. This study did not differentiate whether increased vine nutrition increases the propensity for a visit from a sharpshooter vector or if increased vine nutrition is necessary for $X f$ to increase its population within the grapevine thus causing disease symptoms. What was elicited is the nutrient status of several elements which seem to promote and antagonize increased disease frequency.

Increased levels of five grapevine nutrients were identified as antagonistic to PD development; calcium, boron, magnesium, copper and manganese. These micronutrients may play a role in the inhibition of disease development within the grapevine. Previous studies have identified metallic micronutrients prevent $X f$ in laboratory trials (Darjean et al. 2000). The only vine nutrient negatively correlated with increased severity of PD in this study, and also shown by work from Darjean and associates (2000), to be inhibitory to disease formation, was copper. While higher levels of these micronutrients are inhibiting the bacteria, they are most likely not deterring the insect vectors. I believe certain concentrations of these micronutrients within the grapevine have a bactericidal effect on $X f$ thus preventing the spread of PD within the vine. Further research would have to be conducted to hone in on exact concentrations of these nutrients to reduce $X f$ development. Conversely, further studies are required to determine if deficiencies in nutritional elements identified as promoting increased PD could limit the incidence. 
Our PCR vegetation sampling verified what Freitag concluded in 1951, that the majority of vegetation in California are host plants for $X f$. Suggesting the only missing variable for disease transmission to a grapevine is an efficient vector. The red-headed and blue-green sharpshooters are correlated with northern California vineyard locations which have been shown in previous works to exhibit localized PD epidemics along riparian and grass land corridors (Purcell et al. 1974). This at times causes significant losses throughout grape growing regions of California and contributed to increased disease severity at one study site, Guadagni, in this project. The riparian corridor was shown in this and other works (Purcell 1999b) to promote sharpshooter concentrations suggestive that water availability and host plants were abundant.

In this study, the only sharpshooter not correlated with a vineyard riparian habitat is the GWSS. This suggests the GWSS does not require adjacent riparian habitat to infest vineyard locations. Either the traits of the GWSS (i.e. strong fliers) or environmental conditions (i.e. availability of host plants) allowed the GWSS to maintain a broad distribution in infested locations, as discussed in Blua et al. (1999) and Purcell et al. (1999a). In southern California the GWSS inhabits an urban agriculture interface where the abundance of ornamental plant species provides adequate resources for populations to build and therefore distribute throughout the region.

Few alternatives are available to limit the spread of disease if efficient vectors are present in abundance. In the southeastern United States insecticidal control measures for GWSS have not been successful at preventing the spread of PD (Hopkins et al. 2002). Muscadine grapes, Vitis rotundifolia, are PD resistant and grown in these regions where the disease and GWSS are abundant (Hopkins et al. 2002). If the GWSS is able to 
distribute itself throughout California, as verified in this study the abundance of alternative vegetation that contains $X f$ is significant enough to potentially lead to increased PD severity throughout all growing regions (Freitag 1951). Therefore, PD solutions in California should target vine resistance or altering of vineyard factors to provide a vineyard climate not conducive for increased disease.

The resources in which a grower has to combat PD are few. No individual management tool will solve the problem and the most efficient combination of tools is unknown. Choosing vineyard locations conducive to environmental variables which inhibit disease frequency is one strategy derived from this research. Alternatively, the reduction of environmental variables promoting disease (i.e. adjacent citrus) is advised to reduce potential disease presence. Control measures including moisture control and nutritional applications may have varying consequences on the health and productivity of the vine. Examining increased levels of antagonistic nutritional elements can be a possible solution to reducing the severity of $\mathrm{PD}$ in grapevines. The removal of alternate vineyard vegetation hosts of $X f$ and the introduction of non-pathogenic host plants for sharpshooter feeding are options. All significantly correlating environmental variables, whether positive or negative, should be further analyzed to see what role they play in the development or reduction of disease development.

We hope these results will ultimately contribute to the management of Pierce's disease by identifying to grape growers and pest management practitioners the most important variables in the expression of the disease. 


\section{LITERATURE CITED}

Amacher, Michael C. 1996. Nickel, cadmium, and lead. Pages 739-768. In D. L. Sparks, A. L. Page, P. A. Helmke, R. H. Loeppert, P. N. Soltanpour, M. A. Tabatabai, C. T. Johnston and M. E. Sumner (eds). Methods of soil analysis Part 3 Chemical methods. Soil Science Society of America Book Series number 5, Soil Science Society of America, Inc., American Society of Agronomy, Inc., Madison, WI.

Blua, M. J., Phillips, P. A. and Redak, R. A. 1999. A new sharpshooter threatens both crops and ornamentals. California Agriculture 53: 22-25.

Blua, M. J., Redak, R. A. Morgan, D. J., W. and Costa, H. S. 2001. Seasonal flight activity of two Homalodisca species (Homoptera: Cicadellidae) that spread Xylella fastidiosa in southern California. Journal of Economic Entomology 94(6): 1506-1510.

Brodbeck, B. V., Mizell, R. F, and Andersen, P.C. 1992. Physiological and behavioral adaptations of three species of leafhoppers in response to the dilute nutrient content of xylem fluid. Journal of Insect Physiology 39: 73-81.

Christensen, P., Kasimatis, A., Jensen, F. 1978. Grapevine nutrition and fertilization in the San Joaquin Valley. University of California, Priced Publication 4087, USA.

Costa, H. S., Raetz, E. and Pinckard, T. R. 2004. Plant hosts of Xylella fastidiosa in and near southern California vineyards. Plant Disease 88: 1255-1261.

Darjean, D. H., Civrolo, E. L. C. and Kirkpatrick, B. C. 2000. In Vitro grwth inhibition of Xylella fastidosa by selected metallic plant micronutrients and antibiotics. Phytopathology 90: S17.

Davis, M. J., Purcell A. H. and Thomson S. V. 1978. Pierce's disease of grapevines: Isolation of the causal bacterium. Science 199:75-77.

DeLong, D. M., and Severin, H. H. P. 1950. Spittle-insect vectors of Pierce's Disease virus I. Characters, distribution, and food plants. Hilgardia 19: 339-355.

Feil, H., Feil, W. S. and Purcell, A. H. 2003. Effects of date of inoculation on the withinplant movement of Xylella fastidiosa and persistence of Pierce's disease within field grapevines. Phytopathology 93(2): 244-251.

Frazier, N. W. 1943. Transmission by ten species of leafhoppers of the virus causing Pierce's disease of grapevines and dwarf of alfalfa. Entomology. Berkeley, University of California: 60.

Freitag, J. H. 1951. Host range of the Pierce's disease virus of grapes as determined by insect transmission. Phytopathology 41: 920-932. 
Fry, S. M. and Milholland, R. D. 1988. Multiplication and translocation of the Pierce's disease bacterium in grapevines. Phytopathology 78(12 PART 1): 1541.

Gardner, M. W. and Hewitt, W. B. 1974. Pierce's disease of the grapevine: The Anaheim disease and the California vine disease. Berkeley and Los Angeles: Univ. Calif. Press.

Goheen, A. C., Nyland G. and Lowe S. K. 1973. Association of a rickettsia-like organism with Pierce's disease of grapevines and alfalfa dwarf and heat therapy of the disease in grapevines. Phytopathology 63:341-345.

Goodwin, P. H., DeVay, J. E., and Meredith, C. P. 1988. Roles of water stress and phytotoxins in the development of Pierce's disease of the grapevine. Physiol. Mol. Plant Pathol. 32:1-15.

Goodwin, P., and Purcell, A. H. 1992. Pierce's disease. Grape pest management, 2nd Edition. Oakland, University of California, Division of Agriculture and Natural Resources: 76-84.

Grambell, R. P. 1996. Manganese. Pages 665-682. In D. L. Sparks, A. L. Page, P. A. Helmke, R. H. Loeppert, P. N. Soltanpour, M. A. Tabatabai, C. T. Johnston and M. E. Sumner (eds). Methods of soil analysis Part 3 Chemical methods. Soil Science Society of America Book Series number 5, Soil Science Society of America, Inc., American Society of Agronomy, Inc., Madison, WI.

Helmke, Philip A. and Sparks, Donald L. 1996. Lithium, sodium, potassium, rubidium, and cesium. Pages 551-574. In D. L. Sparks, A. L. Page, P. A. Helmke, R. H. Loeppert, P. N. Soltanpour, M. A. Tabatabai, C. T. Johnston and M. E. Sumner (eds). Methods of soil analysis Part 3 Chemical methods. Soil Science Society of America Book Series number 5, Soil Science Society of America, Inc., American Society of Agronomy, Inc., Madison, WI.

Hewitt, W. B., Frazier, N. W., Jacob, H. E., and Freitag, J. H. 1942. Pierce's Disease of Grapevines. University of California College of Agriculture. Agricultural Experiment Station, Berkeley, California. Circular 35327 p.

Hill, B. L. and Purcell, A. H. 1995. Acquisition and Retention of Xylella fastidiosa by an Efficient Vector, Gaphocephala atropunctata. Phytopathology 85: 209-212.

Hopkins, D. L. and Mollenhauer, H. H. 1973. Rickettsia-like bacterium associated with Pierce's disease of grapes. Science 179: 298-300.

Hopkins, D. L. 1983. Gram-negative xylem-limited bacteria in plant disease. Phytopathology 73(2): 347-350. 
Hopkins, D. L. 1985. Water stress in grapevines with Pierce's disease. Phytopathology 75(4): 500.

Hopkins, D. L. 1991. Colonization of grapevine by various strains of Xylella fastidiosa. Phytopathology 81(7): 812.

Hopkins, D. L. and Purcell, A. H. 2002. Xylella fastidiosa: Cause of Pierce's disease of grapevine and other emergent diseases. Plant Disease 86(10): 1056-1066.

Kuo, Shiou. 1996. Phosphorus. Pages 869-919. In D. L. Sparks, A. L. Page, P. A. Helmke, R. H. Loeppert, P. N. Soltanpour, M. A. Tabatabai, C. T. Johnston and M. E. Sumner (eds). Methods of soil analysis Part 3 Chemical methods. Soil Science Society of America Book Series number 5, Soil Science Society of America, Inc., American Society of Agronomy, Inc., Madison, WI.

Loeppert, Richard L. and Inskeep, W. P. Iron. Pages 639-664. In D. L. Sparks, A. L. Page, P. A. Helmke, R. H. Loeppert, P. N. Soltanpour, M. A. Tabatabai, C. T. Johnston and M. E. Sumner (eds). Methods of soil analysis Part 3 Chemical methods. Soil Science Society of America Book Series number 5, Soil Science Society of America, Inc., American Society of Agronomy, Inc., Madison, WI.

Lindow, S. 2001. The Role of Cell-Cell Signaling in Host Colonization by Xylella fastidiosa. Glassy-winged Sharpshooter and Pierce's disease research summaries. California Department of Food and Agriculture.

Machado, M. A., de Souza, A. A., Filho, H. D. C., Kuramae, E. E. and Takita, M. A. 2001. Genome and pathogenicity of Xylella fastidiosa. Molecular Biology Today 2(3): 33-43.

Minsavage, G. V., Thompson, C. M., Hopkins, D. L., Leite, B. C. and Stall, R. E. 1994. Development of a Polymerase Chain Reaction Protocol for the Detection of Xylella fastidiosa in Plant Tissue. Phytopathology 84: 456-462.

Mulvaney, R. L. 1996. Nitrogen - Inorganic forms. Page 1123-1184. In D. L. Sparks, A. L. Page, P. A. Helmke, R. H. Loeppert, P. N. Soltanpour, M. A. Tabatabai, C. T. Johnston and M. E. Sumner (eds). Methods of soil analysis Part 3 Chemical methods. Soil Science Society of America Book Series number 5, Soil Science Society of America, Inc., American Society of Agronomy, Inc., Madison, WI.

Phillips, P. 1998. The glassy-winged sharpshooter: a potential threat to California citrus. Citrograph 83: 10-12.

Pierce, Newton B. 1892. The California vine disease. (Prelim. Report) Bulletin US Division of Vegetable Pathology. 2: 1-222. 
Purcell, A. H. 1974. Spatial patterns of Pierce's disease in the Napa Valley. American Journal of Enology and Viticulture 25(3):162-167.

Purcell, A. H. 1975. Role of the blue-green sharpshooter, Hordinia circellata, in the epidemiology of Pierce's disease of grapevines. Environmental Entomology 4: 745-752.

Purcell, A. H.1976. Seasonal changes in host plant preference of the blue-green sharpshooter Hordnia circellata (Homoptera: Cicadellidae). Pan-Pacific Entomologist 52(11): 33-37.

Purcell, A. H.1981.Vector preference and inoculation efficiency as components of resistance to Pierce' disease in European grape Vitis vinifera Cultivars. Phytopathology 71(4): 429-435.

Purcell, A. H. and Frazier N. W. 1985. Habitats and dispersal of the principal leafhopper vectors of Pierce's disease in the San-Joaquin Valley California USA. Hilgardia 53(4): 1-32.

Purcell, A. H. and Saunders, S. R. 1999a. Glassy-winged sharpshooters expected to increase plant disease. California Agriculture 53(2): 26-27.

Purcell, A. H. and Saunders, S. R. 1999b. Fate of Pierce's disease strains of Xylella fastidiosa in common riparian plants in California. Plant Disease. 83: 825-830.

Raju, B. C., Nome, S. F., Docampo, D. M., Goheen, A. C., Nyland, G. and Lowe, S. K. 1980. Alternative hosts of Pierce's disease of grapevines that occur adjacent to grape growing areas in California USA. American Journal of Enology \& Viticulture 31(2): 144-148.

Raju, B. C., Goheen, Austin C., and Frazier, Norman W. 1983. Occurrence of Pierce's disease bacteria in plants and vectors in California USA. Phytopathology 73(9): 1309-1313.

Reed, Stewart T. and Martens, D. C. 1996. Copper and zinc. Pages 703-722. In D. L. Sparks, A. L. Page, P. A. Helmke, R. H. Loeppert, P. N. Soltanpour, M. A. Tabatabai, C. T. Johnston and M. E. Sumner (eds). Methods of soil analysis Part 3 Chemical methods. Soil Science Society of America Book Series number 5, Soil Science Society of America, Inc., American Society of Agronomy, Inc., Madison, WI.

Rhoades, J. D. 1996. Salinity: Electrical conductivity and total dissolved solids. Pages 417-435. In D. L. Sparks, A. L. Page, P. A. Helmke, R. H. Loeppert, P. N. Soltanpour, M. A. Tabatabai, C. T. Johnston and M. E. Sumner (eds). Methods of soil analysis Part 3 Chemical methods. Soil Science Society of America Book 
Series number 5, Soil Science Society of America, Inc., American Society of Agronomy, Inc., Madison, WI.

Sims, John L. 1996. Molybdenum and cobalt. Pages 723-737. In D. L. Sparks, A. L. Page, P. A. Helmke, R. H. Loeppert, P. N. Soltanpour, M. A. Tabatabai, C. T. Johnston and M. E. Sumner (eds). Methods of soil analysis Part 3 Chemical methods. Soil Science Society of America Book Series number 5, Soil Science Society of America, Inc., American Society of Agronomy, Inc., Madison, WI.

Simpson, A. J. G., Reinach, F. C., Arruda, P., Areu. F. A., Acencio, M. 2000. The genome sequence of the plant pathogen Xylella fastidiosa. Nature 406:151-157.

Sorensen, J. T. and Gill, R. J. 1996. A range expansion of Homalodisca coagulata (Say) (Hemiptera: Clypeorrhyncha: Cicadellidae) to southern California. Pan-Pacific Entomologist 72(3): 160-161.

Suarez, Donald L. 1996. Beryllium, magnesium, calcium, strontium, and barium. Pages 575-601. In D. L. Sparks, A. L. Page, P. A. Helmke, R. H. Loeppert, P. N. Soltanpour, M. A. Tabatabai, C. T. Johnston and M. E. Sumner (eds). Methods of soil analysis Part 3 Chemical methods. Soil Science Society of America Book Series number 5, Soil Science Society of America, Inc., American Society of Agronomy, Inc., Madison, WI.

Sumner, Malcolm E. and. Miller, William P. 1996. Cation exchange capacity and exchange coefficients. Pages 1201-1229. In D. L. Sparks, A. L. Page, P. A. Helmke, R. H. Loeppert, P. N. Soltanpour, M. A. Tabatabai, C. T. Johnston and M. E. Sumner (eds). Methods of soil analysis Part 3 Chemical methods. Soil Science Society of America Book Series number 5, Soil Science Society of America, Inc., American Society of Agronomy, Inc., Madison, WI.

Tabatabai, M. A. 1996. Sulfur. Pages 921-960. In D. L. Sparks, A. L. Page, P. A. Helmke, R. H. Loeppert, P. N. Soltanpour, M. A. Tabatabai, C. T. Johnston and M. E. Sumner (eds). Methods of soil analysis Part 3 Chemical methods. Soil Science Society of America Book Series number 5, Soil Science Society of America, Inc., American Society of Agronomy, Inc., Madison, WI.

Ter Braak, C. J. F. 1986. Canonical correspondence analysis: A new eigenvector technique for multivariate direct gradient analysis. Ecology 67 (5): 1167-1179.

Thomas, Grant W. 1996. Soil pH and soil acidity. Pages 475-490. In D. L. Sparks, A. L. Page, P. A. Helmke, R. H. Loeppert, P. N. Soltanpour, M. A. Tabatabai, C. T. Johnston and M. E. Sumner (eds). Methods of soil analysis Part 3 Chemical methods. Soil Science Society of America Book Series number 5, Soil Science Society of America, Inc., American Society of Agronomy, Inc., Madison, WI. 
Turner, W. F. and Pollard, H. N. 1959. Life history and behavior of five insect vectors of phony peach disease. U.S. Dep. Agric. Tech. Bull. No. 11881959.

VanderMolen, G. E., Labavitch, J. M., Strand, L. L., and DeVay, J. E. 1983. Pathogeninduced vascular gels: Ethylene as a host intermediate. Physiol. Plant. 59: 573580.

Van Sluys, M. A., de Oliveira, M. C., Monwieo-Vitorello, C. B., Miyaki, C. Y., Furlan, L. R. 2003. Comparative analyses of the complete genome sequences of Pierce's disease and citrus variegated chlorosis strains of Xylella fastidiosa. J. Bacteriol. 185:1018-1026.

Young, D. A. 1958. A synopsis of Homalodisca in the United States (Homoptera, Cicadellidae). Brooklyn Entomological Society Bulletin 53: 7-13. 
APPENDIX: Environmental Variable Data 2002-2003

Table 10. PCR Results for Alternate Vegetation Samples at Study Sites.

\begin{tabular}{|c|c|c|c|c|c|}
\hline Plant Species & Scientific & Site & Location & Date & PCR test \\
\hline \multirow[t]{3}{*}{ Alder } & Alnus sp. & Beringer & Riparian & $6 / 24 / 03$ & Negative \\
\hline & & & & $9 / 16 / 03$ & Negative \\
\hline & & & & $10 / 21 / 03$ & Negative \\
\hline Annual sowthistle & Sonchus oleraceus & DeBerard & Vineyard & $11 / 1 / 03$ & Positive \\
\hline \multirow[t]{2}{*}{ Annual sowthistle } & Sonchus oleraceus & Callaway 1 & Vineyard & $6 / 17 / 03$ & Positive \\
\hline & & & & $11 / 1 / 03$ & Positive \\
\hline Arundo & Arundo donax & G. Brothers & Riparian & $9 / 4 / 03$ & Negative \\
\hline Black Mustard & Brassica sp. & Callaway 1 & Vineyard & $5 / 15 / 03$ & Positive \\
\hline Barnyard grass & Echinochloa crus/galli & DeBerard & Vineyard & $11 / 1 / 03$ & Positive \\
\hline Bay Laurel & Umbellularia californica & Cain & Riparian & $10 / 21 / 03$ & Positive \\
\hline Bay Laurel & Umbellularia californica & Beringer & Riparian & $10 / 21 / 03$ & Positive \\
\hline Bermuda grass & Cynodon dactylon & Callaway 2 & Vineyard & $11 / 1 / 03$ & Positive \\
\hline Bermuda grass & Cynodon dactylon & G. Brothers & Riparian & $6 / 24 / 03$ & Positive \\
\hline Bermuda grass & Cynodon dactylon & Hofer & Vineyard & $11 / 1 / 03$ & Positive \\
\hline Black Mustard & Brassica sp. & DeBerard & Vineyard & $11 / 1 / 03$ & Positive \\
\hline \multirow[t]{2}{*}{ Black mustard } & Brassica sp. & Beringer & Vineyard & $9 / 16 / 03$ & Positive \\
\hline & & & & $10 / 21 / 03$ & Positive \\
\hline Black Mustard & Brassica sp. & Cain & Vineyard & $10 / 21 / 03$ & Positive \\
\hline \multirow[t]{2}{*}{ Black mustard } & Brassica sp. & Callaway 1 & Vineyard & $6 / 17 / 03$ & Positive \\
\hline & & & & $9 / 11 / 03$ & Positive \\
\hline \multirow[t]{2}{*}{ Black mustard } & Brassica sp. & Callaway 2 & Vineyard & $11 / 1 / 03$ & Positive \\
\hline & & & & $11 / 1 / 03$ & Positive \\
\hline Black Mustard & Brassica sp. & G. Bros & Vineyard & $10 / 21 / 03$ & Positive \\
\hline Black Walnut & Juglans sp. & G. Bros & Riparian & $10 / 21 / 03$ & Negative \\
\hline \multirow[t]{2}{*}{ Blackberry } & Rubus ursinus & Beringer & Riparian & $6 / 24 / 03$ & Positive \\
\hline & & & & $9 / 3 / 03$ & Positive \\
\hline Blackberry & Rubus ursinus & Beringer & Vineyard & $10 / 21 / 03$ & Positive \\
\hline \multirow[t]{3}{*}{ Blackberry } & Rubus ursinus & Cain & Riparian & $6 / 24 / 03$ & Positive \\
\hline & & & & $9 / 4 / 03$ & Positive \\
\hline & & & & $10 / 21 / 03$ & Positive \\
\hline \multirow[t]{5}{*}{ Buckeye } & Aesculus californica & G. Bros & Riparian & $10 / 21 / 03$ & Positive \\
\hline & & & & $10 / 21 / 03$ & Positive \\
\hline & & & & $6 / 24 / 03$ & Positive \\
\hline & & & & $6 / 24 / 03$ & Positive \\
\hline & & & & $6 / 24 / 03$ & Positive \\
\hline Buckhorn plantain & Plantago lanceolata & Beringer & Vineyard & $9 / 16 / 03$ & Negative \\
\hline Buckwheat & Fagopyrum esculentum & Callaway 1 & Vineyard & $6 / 17 / 03$ & Negative \\
\hline
\end{tabular}




\begin{tabular}{|c|c|c|c|c|c|}
\hline & & & & $6 / 17 / 03$ & Negative \\
\hline & & & & $5 / 15 / 03$ & Negative \\
\hline & & & & $11 / 1 / 03$ & Negative \\
\hline Buckwheat & Fagopyrum esculentum & G. Bros & Riparian & $10 / 21 / 03$ & Negative \\
\hline Chickweed & Stellaria media & Callaway 2 & Vineyard & $11 / 1 / 03$ & Positive \\
\hline \multirow[t]{2}{*}{ Citrus } & Citrus sp. & DeBerard & Vineyard & $11 / 1 / 03$ & Positive \\
\hline & & & & $11 / 1 / 03$ & Positive \\
\hline Coast live oak & Quercus agrifolia & Beringer & Riparian & $10 / 21 / 03$ & Positive \\
\hline Coast live oak & Quercus agrifolia & G. Bros & Riparian & $10 / 21 / 03$ & Positive \\
\hline Control grape & Vitis vinifera & Cal Poly & Neg. Control & $12 / 15 / 03$ & Negative \\
\hline Coyote bush & Bassharis pilularis & Beringer & Vineyard & $6 / 24 / 03$ & Negative \\
\hline Coyote bush & Bassharis pilularis & Beringer & Riparian & $9 / 16 / 03$ & Negative \\
\hline Curley dock & Rumex crispus & Callaway 1 & Vineyard & $6 / 17 / 03$ & Positive \\
\hline Curley dock & Rumex crispus & G. Bros & Vineyard & $10 / 21 / 03$ & Positive \\
\hline Elderberry & Sambucus sp. & Beringer & Riparian & $6 / 24 / 03$ & Positive \\
\hline \multirow[t]{4}{*}{ Elderberry } & Sambucus sp. & G. Brothers & Riparian & $6 / 11 / 03$ & Positive \\
\hline & & & & $6 / 24 / 03$ & Negative \\
\hline & & & & $6 / 24 / 03$ & Positive \\
\hline & & & & $6 / 24 / 03$ & Positive \\
\hline Filaree & Erodium cicutarium & DeBerard & Vineyard & $11 / 1 / 03$ & Positive \\
\hline \multirow[t]{2}{*}{ Grape } & Vitis vinifera & DeBerard & Vineyard & $9 / 11 / 03$ & Positive \\
\hline & & & & $9 / 11 / 03$ & Positive \\
\hline Grape & Vitis vinifera & Beringer & Vineyard & $10 / 21 / 03$ & Positive \\
\hline Grape & Vitis vinifera & Cain & Vineyard & $9 / 4 / 03$ & Positive \\
\hline Grape & Vitis vinifera & DeBerard & Vineyard & $11 / 1 / 03$ & Positive \\
\hline \multirow[t]{2}{*}{ Grapefruit } & Citrus sp. & Callaway 1 & Vineyard & $5 / 15 / 03$ & Positive \\
\hline & & & & $6 / 17 / 03$ & Positive \\
\hline Hairy fleabane & Conyza bonariensis & DeBerard & Vineyard & $11 / 1 / 03$ & Positive \\
\hline Hemlock & Conium maculatum & G. Brothers & Riparian & $6 / 24 / 03$ & Positive \\
\hline Horse Purslane & $\begin{array}{l}\text { Trianthena } \\
\text { portulacastrum }\end{array}$ & G. Bros & Vineyard & $10 / 21 / 03$ & Negative \\
\hline Horse weed & Conyza canadensis & DeBerard & Vineyard & $11 / 1 / 03$ & Positive \\
\hline Horse weed & Conyza canadensis & Callaway 1 & Vineyard & $6 / 17 / 03$ & Positive \\
\hline Horse weed & Conyza canadensis & Hofer & Vineyard & $11 / 1 / 03$ & Positive \\
\hline Ivy & Hedera sp. & DeBerard & Vineyard & $9 / 11 / 03$ & Positive \\
\hline Jimson weed & Datura stramonium & Hofer & Vineyard & $11 / 1 / 03$ & Positive \\
\hline Jimson weed & Datura stramonium & G. Bros & Vineyard & $10 / 21 / 03$ & Positive \\
\hline Juniper & Juniperus sp. & DeBerard & East wall & $11 / 1 / 03$ & Negative \\
\hline Maple & Acer sp. & Cain & Riparian & $10 / 21 / 03$ & Positive \\
\hline Marestail & Conyza canadensis & Cain & Riparian & $10 / 21 / 03$ & Positive \\
\hline \multirow[t]{2}{*}{ Mugwort } & Artemisia douglasiana & Beringer & Riparian & $9 / 3 / 03$ & Positive \\
\hline & & & & $9 / 3 / 03$ & Positive \\
\hline
\end{tabular}




\begin{tabular}{|c|c|c|c|c|c|}
\hline Mugwort & Artemisia douglasiana & G. Brothers & Riparian & $6 / 24 / 03$ & Negative \\
\hline Mulefat & Baccharis salicifolia & Cain & Vineyard & $10 / 21 / 03$ & Positive \\
\hline Mustard & Brassica sp. & Cain & Vineyard & $10 / 21 / 03$ & Positive \\
\hline Native honeysuckle & Lonicera sp. & Cain & Riparian & $9 / 4 / 03$ & Positive \\
\hline $\begin{array}{l}\text { Nettleleaf } \\
\text { goosefoot }\end{array}$ & Chenopodium murale & Hofer & Vineyard & $11 / 1 / 03$ & Positive \\
\hline Nutsedge & Cyprus sp. & Beringer & Riparian & $9 / 16 / 03$ & Positive \\
\hline Oleander & Nerium sp. & DeBerard & Vineyard & $11 / 1 / 03$ & Positive \\
\hline Peppermint & Mentha sp. & Beringer & Riparian & $9 / 16 / 03$ & Positive \\
\hline Pigweed & Amaranthus retroflexus & Hofer & Vineyard & $5 / 15 / 03$ & Positive \\
\hline Plum & Prunus sp. & G. Brothers & Riparian & $6 / 24 / 03$ & Positive \\
\hline Poison Hemlock & Conium maculatum & G. Bros & Riparian & $10 / 21 / 03$ & Positive \\
\hline \multirow[t]{2}{*}{ Prickly lettuce } & Lactuca serriola & Callaway 1 & Vineyard & $6 / 17 / 03$ & Positive \\
\hline & & & & $6 / 17 / 03$ & Positive \\
\hline Prickly lettuce & Lactuca serriola & G. Bros & Vineyard & $10 / 21 / 03$ & Positive \\
\hline Puncture Vine & Tribulus terrestris & Hofer & Vineyard & $5 / 15 / 03$ & Positive \\
\hline Purslane & Portulaca oleracea & DeBerard & Vineyard & $11 / 1 / 03$ & Negative \\
\hline Redroot pigweed & Amaranthus retroflexus & Callaway 2 & Vineyard & $11 / 1 / 03$ & Positive \\
\hline Redroot pigweed & Amaranthus retroflexus & Callaway 1 & Vineyard & $6 / 17 / 03$ & Positive \\
\hline Redroot pigweed & Ameranthus retroflexus & G. Bros & Vineyard & $10 / 21 / 03$ & Positive \\
\hline Reed & Equisetum arvense & Callaway 2 & Riparian & $11 / 1 / 03$ & Positive \\
\hline Rosemary & Rosmarinus officinalis & Hofer & Vineyard & $11 / 1 / 03$ & Positive \\
\hline \multirow[t]{3}{*}{ Russian thistle } & Salsola iberica & Callaway 1 & Vineyard & $6 / 17 / 03$ & Positive \\
\hline & & & & $9 / 11 / 03$ & Positive \\
\hline & & & & $11 / 1 / 03$ & Positive \\
\hline Rye grass & Lolium multiflorum & G. Brothers & Riparian & $6 / 24 / 03$ & Negative \\
\hline Scrub oak & Quercus domosa & Beringer & Riparian & $9 / 16 / 03$ & Negative \\
\hline \multirow[t]{3}{*}{ Snow Berry } & Symphoricarpos albus & G. Bros & Riparian & $10 / 21 / 03$ & Positive \\
\hline & & & & $10 / 21 / 03$ & Positive \\
\hline & & & & $6 / 24 / 03$ & Negative \\
\hline Sycamore & Platanus sp. & Hofer & Vineyard & $5 / 15 / 03$ & Positive \\
\hline Sycamore & Platanus sp. & Hofer & Vineyard & $11 / 1 / 03$ & Positive \\
\hline \multirow[t]{3}{*}{ Telegraph weed } & Heterotheca grandifolia & Callaway 1 & Vineyard & $5 / 15 / 03$ & Positive \\
\hline & & & & $6 / 17 / 03$ & Positive \\
\hline & & & & $11 / 1 / 03$ & Positive \\
\hline Turkey mullein & Eremocarpus setigerus & Beringer & Vineyard & $9 / 16 / 03$ & Positive \\
\hline \multirow[t]{2}{*}{ Turkey mullein } & Eremocarpus setigerus & Callaway 1 & Vineyard & $5 / 15 / 03$ & Positive \\
\hline & & & & $6 / 17 / 03$ & Positive \\
\hline \multirow[t]{3}{*}{ Vinca } & Vinca major & G. Bros & Riparian & $10 / 21 / 03$ & Negative \\
\hline & & & & $10 / 21 / 03$ & Negative \\
\hline & & & & $6 / 24 / 03$ & Negative \\
\hline Wild grape & Vitis californica & Beringer & Riparian & $6 / 24 / 03$ & Positive \\
\hline
\end{tabular}




\begin{tabular}{|l|l|l|l|c|c|}
\hline & & & & $9 / 3 / 03$ & Negative \\
\hline Wild Grape & Vitis californica & G. Bros & Riparian & $10 / 21 / 03$ & Positive \\
\hline & & & & $6 / 24 / 03$ & Positive \\
\hline & Salix sp. & Beringer & Riparian & $6 / 24 / 03$ & Positive \\
\hline & & & & $10 / 21 / 03$ & Positive \\
\hline & Salix sp. & Cain & Riparian & $6 / 24 / 03$ & Positive \\
\hline & & & & $6 / 24 / 03$ & Positive \\
\hline & & & & $9 / 4 / 03$ & Positive \\
\hline & & & & $9 / 4 / 03$ & Positive \\
\hline Willow & & & & $10 / 21 / 03$ & Positive \\
\hline & Salix sp. & G. Bros & Riparian & $10 / 21 / 03$ & Positive \\
\hline & & & & $10 / 21 / 03$ & Positive \\
\hline & & & & $6 / 24 / 03$ & Positive \\
\hline Willow & & & & $6 / 24 / 03$ & Positive \\
\hline Yellow nutsedge & Cyprus esculentus & Hofer & Vineyard & $5 / 15 / 03$ & Positive \\
\hline & & & & $11 / 1 / 03$ & Positive \\
\hline Yellow sweetclover & Melilotus officinalis & Callaway 1 & Vineyard & $6 / 17 / 03$ & Positive \\
\hline
\end{tabular}

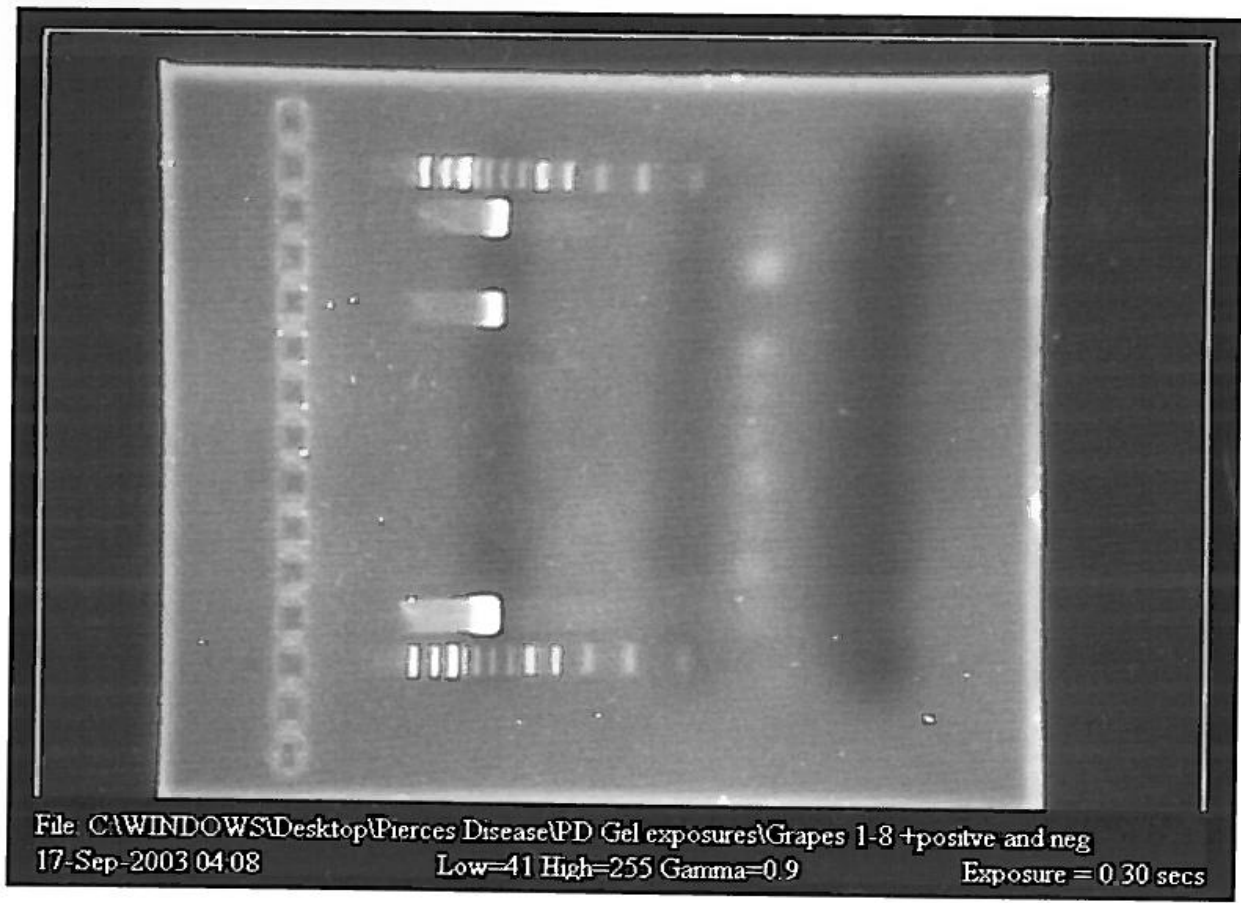

Figure 6. PCR Agarose Gel Image of Grapevine and Vegetation Samples. 


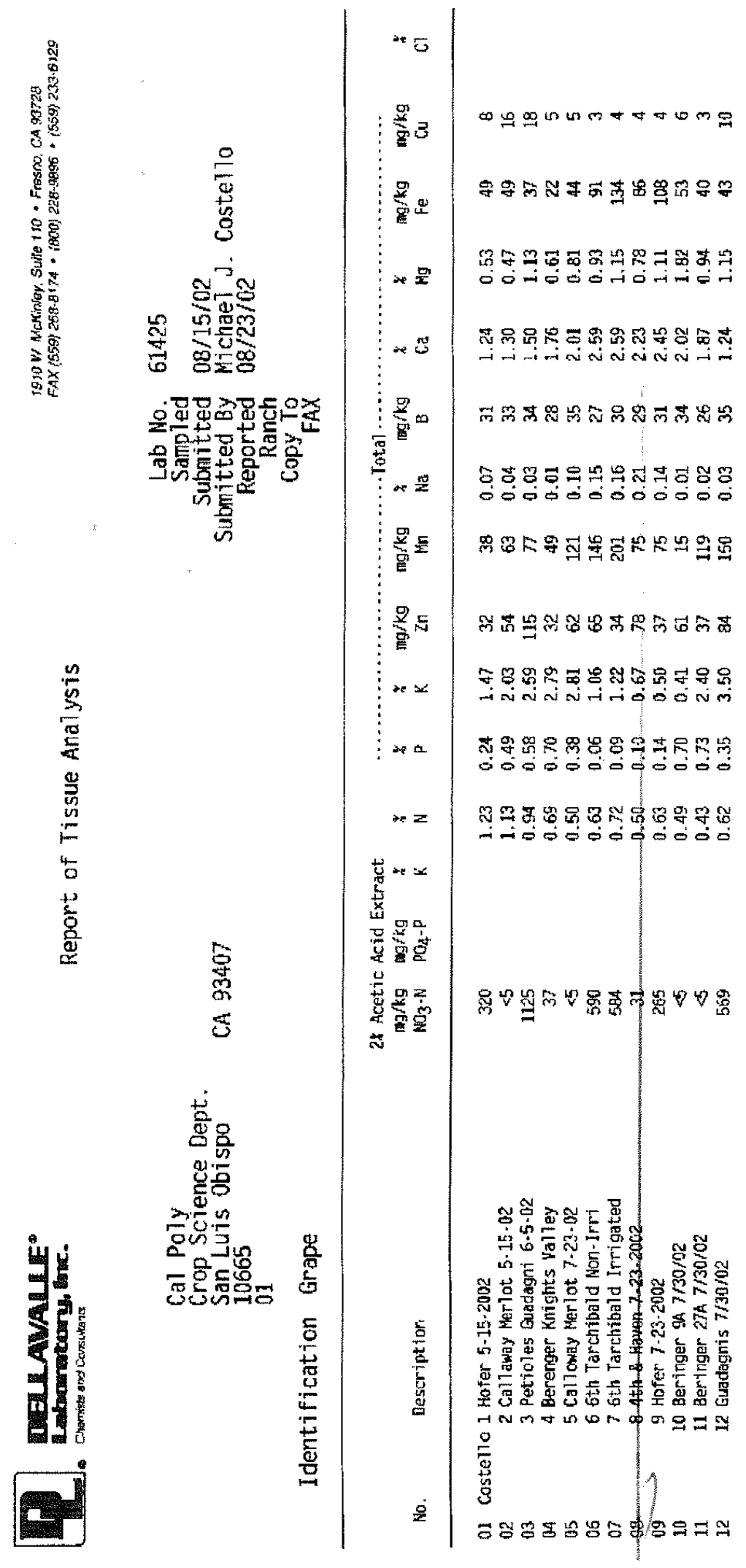

Figure 7. Nutritional Petiole Analysis for Study Sites 2002. 


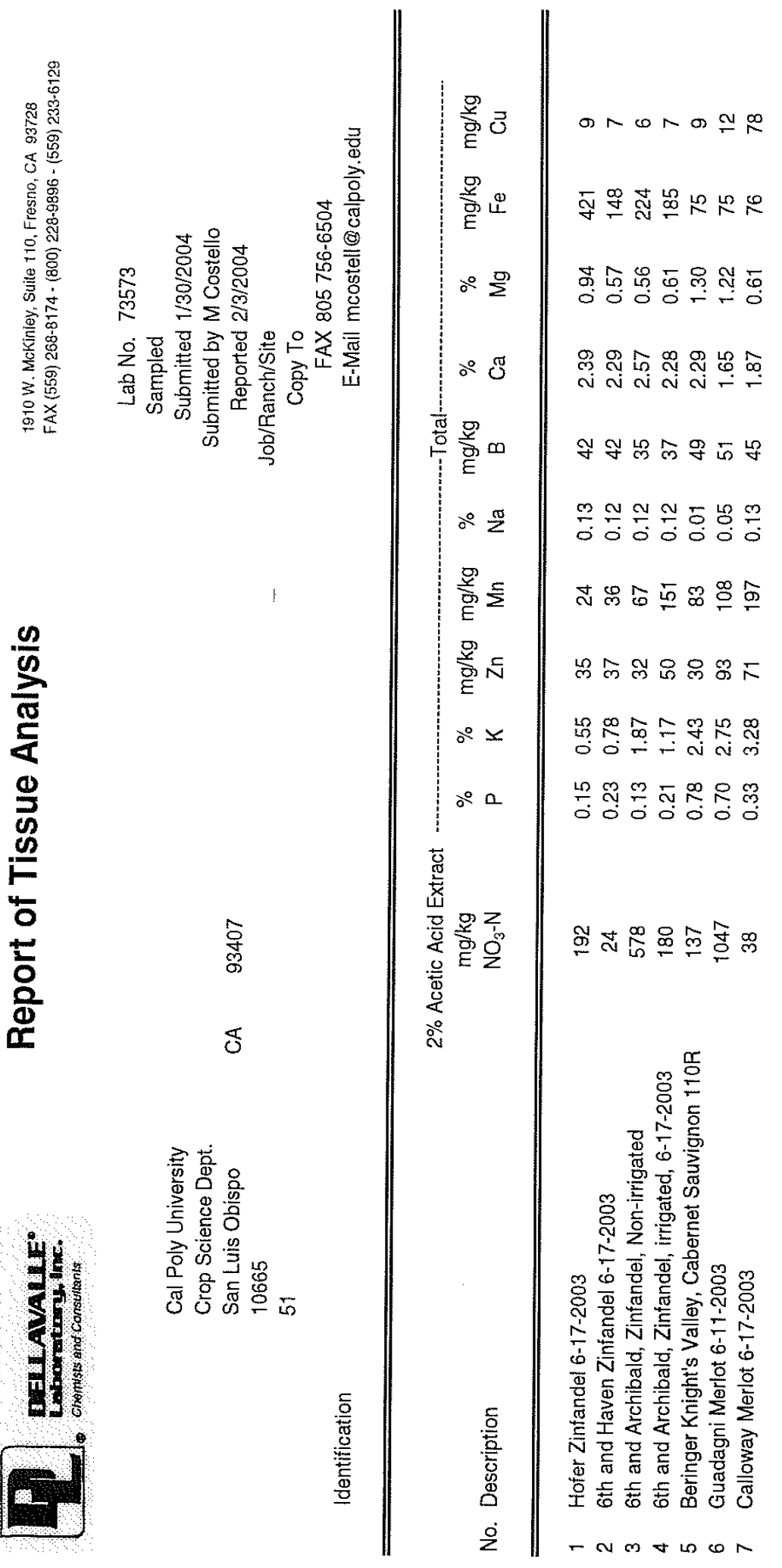

Figure 8. Nutritional Petiole Analysis for Study Sites 2003. 